\title{
Antitrust and the Internet Standardization Problem
}

\author{
Mark A. Lemley
}

It's a very strange time to be an antitrust lawyer, particularly in the information industry. Companies and antitrust regulators regularly do things that seem utterly incomprehensible to anyone schooled in classical antitrust doctrine. Manufacturers of computer hardware and peripherals actually advertise the fact that they have a dominant market position, hoping that that fact will encourage still more people to buy their products. ${ }^{3}$ The largest computer software company in the world announces publicly that it plans to give its newest product away for free -- not just for a limited period, but indefinitely. ${ }^{4}$ Antitrust plaintiffs complain that their competitors won't share enough product data with them, ${ }^{5}$ and the Federal Trade Commission orders information-sharing among competitors as a remedy for potential antitrust problems. ${ }^{6}$ This doesn't look like the world of Chief Justice Warren, who

1 Copyright 1996 Mark A. Lemley (mlemley@mail.law.utexas.edu).

2 Assistant Professor, University of Texas School of Law. Of counsel, Fish \& Richardson P.C., Austin, Texas. I would like to thank Ed Cavazos, Julie Cohen, Michael Froomkin, Lino Graglia, Rose Hagan, Brian Kahin, Doug Laycock, Dick Markovits, David McGowan, Mark Patterson, David Post, Gary Reback, Joel Reidenberg, Bob Schwartz, David Seidman, Jane Winn, Dennis Yao, and the participants in symposia at the United States Department of Justice Antitrust Division, the University of Connecticut, and the University of Texas for their helpful suggestions.

3 See Canon advertisement, 3.11 Wired 211 (Nov. 1995) (Canon market share data); http://www.sun.com/corporateoverview/Facts.html (Sun market share data).

4 Peter H. Lewis, Microsoft to Give Away Web Server Software, N.Y. Times, Feb. 6, 1996, at C6. Microsoft is not alone. See The Java Saga, 3.12 Wired 244 (1995) (quoting Sun Java executive as claiming that Sun's Java source code is "priced below our cost . . It's a strategic investment in market share.").

5 Katie Fairbank, Bell Atlantic, DSC bring antitrust charges against AT\&T, Austin Am.-Statesman, Feb. 16, 1996, at D7.

6 Silicon Graphics, Inc. Proposed Consent AgreementNo. 951-0064, 60Fed. Reg. 128 (July 5, 1995). 
wrote that the antitrust laws embodied "Congress' desire to promote competition through the protection of viable, small, locally owned businesses."7 Nor for that matter does it resemble the world of Adam Smith, himself not a noted antitrust liberal, who wrote that "[p]eople of the same trade seldom meet together, even for merriment and diversion, but the conversation ends in a conspiracy against the public, or in some contrivance to raise pricess."

Something very unusual is going on here. Antitrust has been turned on its head in the last thirty years, ${ }^{9}$ but that fact alone is not sufficient to explain what is happening in the information industries. There is something about the information industry in general and the Internet in particular that makes the application of normal antitrust rules problematic, whether you approach them from the point of view of classical antitrust scholarship or of the Chicago School. In this article, I attempt to explain why antitrust law struggles with conditions in the computer industry, using the Internet as my primary example. Specifically, in Part I, I suggest that a variety of economic factors affecting the computer industry in general, and which apply to the Internet with particular force, make product standardization almost inevitable. In Part II, I explore the implications of this standardization incentive for market structure and firm behavior. Those implications are critical from an antitrust perspective, since they challenge the assumption that markets will (or should) be composed of numerous competitors who lack market power. Finally, in Part III I argue that antitrust law as it has developed historically is

7 Brown Shoe Co. v. United States, 370 U.S. 294 (1962).

8 Adam Smith, The Wealth of Nations 214 (J.R. McCullough ed. 1828). To be fair, Smith did qualify this statement in a footnote by observing that such conspiracies were rarely successful, since the conspirators were inclined to cheat. Id. at $214 \mathrm{n}$.*.

9 There has been a revolution in antitrust doctrine, led by the Chicago school. See Eleanor Fox, The Battle for the Soul of Antitrust, 75 Cal. L. Rev. 917 (1987); William H. Page, The Chicago School and the Evolution of Antitrust: Characterization, Antitrust Injury, and Evidentiary Sufficiency, 75 Va. L. Rev. 1221 (1989). But even the success of this revolution has not altered the fundamental tenets of antitrust doctrine outlawing cartels and monopolization, though it has certainly changed the way in which antitrust claims are evaluated and the number of cases in which an antitrust violation is found. See infra note __ (discussing the shift in approaches to antitrust law). 
unable to cope effectively with such a standardization-driven industry, and offer some suggestions as to how antitrust should -- and should not -- react to developments in the Internet software area. Specifically, I propose that antitrust scrutiny of standardized markets under section 2 of the Sherman Act be limited to efforts to police standards competitions to prevent market-tipping conduct. I also argue that section 1 of the Sherman Act should treat joint standard-setting organizations as generally procompetitive forces in standardized markets, and that antitrust scrutiny of such groups should focus on potential anticompetitive behavior by firms within such a group.

\section{Standardization and the Internet}

There is no question that the Internet is big -- both in the sense that it is a hot topic of discussion, and in the sense that many people, companies, universities and governments are now connected to it. ${ }^{10}$ The Internet is also widely viewed as out of control. This is not true, at least if by "out of control" one means that there are no rules governing how the Internet works. There are abundant rules "governing" the Internet -- the naming rules enforced by InterNIC, ${ }^{11}$ the technical standards set by the Internet Engineering Task Force (IETF), ${ }^{12}$ and

\footnotetext{
10 At this point, it appears to be de rigeur to say something prescient about how important the Internet will become, how ubiquitous it already is, or how it will change our lives. As that has already been done to great effect elsewhere, I will simply direct the reader there. See, e.g., Steven A. Bredice, Comment, Media Hybrids and the First Amendment: Constitutional Signposts Along the Information Superhighway, 44 Emory L.J. 213 (1995); Jane C. Ginsburg, Putting Cars on the "Information Superhighway": Authors, Exploiters, and Copyright in Cyberspace, 95 Colum. L. Rev. 1466 (1995); Albert Halprin, Drive Smoothly to Get on the Information Superhighway, 39 Fed. Comm. L.J. 251 (1994); Eric Handelman, Comment, Obscenity and the Internet: Does the Current Obscenity Standard Provide Individuals with the Proper Constitutional Safeguards, 59 Alb. L. Rev. 709 (1995); Ilene Knable Gotts \& Alan D. Rutenberg, Navigating the Global Information Superhighway: A Bumpy Road Lies Ahead, 8 Harv. J.L. \& Tech. 275 (1995); Donald E. Lively, The Information Superhighway: A First Amendment Roadmap55 B.C.L. Rev. 1067 (1994).
}

11 The interaction between InterNIC's "first-come, first-serve" rule for allocating Internet domain names and trademark law has been explored elsewhere. See, e.g., Dan L. Burk, Trademarks Along the Infobahn: A First Look at the Emerging Law of Cybermarks, 1 Rich. J.L. \& Tech. 1 (1995); Gary W. Hamilton, Trademarks on the Internet: Confusion, Collusion, or Dilution?, 4 Tex. Intell. Prop. L.J.1 (1995); James West Marcovitz, ronald@mcdonalds.com -- "Owning a Bitchin"" Corporate Trademark as an Internet Address -$\begin{array}{llllllll}\text { Infringement?, } & 17 & \text { Cardozo } & \text { L. } & \text { Rev. } & 85 & \text { (1995). }\end{array}$ 
the standards set by individuals and companies who write programs like Mosaic, Eudora, and InContext Spider that operate on the Internet. ${ }^{13}$ The Internet is "out of control" only in the much more limited sense that nature or the capitalist economy are out of control -- it is run on a distributed rather than a centralized basis

Indeed, even the absence of a centralized Internet "government" is misleading in one sense. For there are powerful economic forces at work that tend to standardize Internet products and processes. Modern economic literature is replete with discussions of "network externalities" and "switching costs" in a wide variety of markets, from keyboards to VCRs to parts and service for durable goods. ${ }^{15}$ Economists vigorously debate the existence and

http://www.ll.georgetown.edu/lc/internic/domain1.html (cataloguing information about domain name trademark disputes). On an effort to challenge those rules, see Roderick Simpson, Dueling Domains, Wired, Aug. 1996, at 64.

12 For a discussion of standard-setting in the all-volunteer IETF, see A. Michael Froomkin, A Model of International Law and Society 16-22 (working paper 1995); A. Michael Froomkin, The Internet as a Source of Regulatory Arbitrage (working paper 1996), available at http://www.law.miami.edu/ froomkin/arbitr.htm; Lehr, supra note _, at 131-37; Paulina Borsook, How Anarchy Works, 3.10 Wired 110 (Oct. 1995). The fundamental Internet standard is the Transmission Control Protocol/Internet Protocol, universally abbreviated TCP/IP. TCP/IP governs the interaction of remote computers which need not be in direct contact, through what is known as "packet-switching" of data. It is interesting, and for our purposes perhaps instructive, that the quasi-"official" body designing computer and communications standards, the International Standards Organization (ISO), during the 1980s refused to accept TCP/IP as a networking standard. Instead, the ISO offered its own standard, called Open Systems Interconnection (OSI). OSI failed to replace the basic TCP/IP standard, which continues to govern the Internet.See Froomkin, supra, at 15.

13 To this list should be added a fourth group, the standards requested (but not directly promulgated) by the American National Standards Institute, ANSI. ANSI has set up a working group to identify circumstances in which Internet standards are needed and do not yet exist, presumably in order to encourage private development of such standards. See Kenneth H. Skilling, ANSI Panel Developing Framework for NII Standards 1 Elec. Info. Pol. \& L. Rpt. (BNA)13, 14 (April 12, 1996).

14 See Kevin Kelly, Out of Control (1994) (discussing distributed and evolutionary systems both in nature and in economics); David G. Post, Anarchy, State, and the Internet: An Essay on Law-Making in Cyberspace, 1995 J. Online L. art. 3, IIII 21-22 (http://www.law.cornell.edu/jol/jol.table.html) (technical interface specfications are part of the law of cyberspace); Joel R. Reidenberg, Governing Networks and Cyberspace Rule-Making, 45 Emory L.J. _ (forthcoming 1996) (Internet "is not a lawless place"; the rules are merely to be found in new places).

15 See, e.g. Brian Arthur, Competing Technologies, Increasing Returns, and Lock-in by Historical Events, 99 Econ. J. 116 (1989); Michael Cusumano, Yiorgos Mylondadis, \& Richard Rosenbloom, Strategic Maneuvering and Mass Market Dynamics: The Triumph of VHS Over Beta, Working Paper No. 90-5, Center 
significance of these problems in terms both theoretical and empirical. ${ }^{16}$ In the unique context of the Internet, though, it seems indisputable that the market is driven towards standardization by a variety of forces. In this section, I identify three such forces at work.

\section{A. Network Externalities}

First, the value of the Internet is precisely that it connects people to other people. As with telephone networks, much (but not all) of the "product" being offered is not pure information, but the chance to connect with other consumers. The more people that are connected to the Internet, the more valuable the connection is to each of the members. The fact that value to consumers is so heavily dependent on adoption by others makes the Internet a rare example of the "strong" form of network externality. ${ }^{17}$ Because of this network effect, the optimal number of "Internets" in a free market economy is one, just as the optimal number

for Research in Management, Haas School of Business, U.C. Berkeley (1990); Paul A. David, Clio and the Economics of QWERTY, 75 Am. Econ. Rev. 332 (1985); Joseph Farrell, Standardization and Intellectual Property, 30 Jurimetrics J. 35, 37 (1989); Michael L. Katz \& Carl Shapiro, Systems Competition and Network Effects, 8 J. Econ. Persp.93 (1994).

16 For example, one of the most commonly cited instances of a network externality inhibiting the development of technologically superior products is the QWERTY typewriter keyboard, which (according to the basic story) was deliberately designed to be inefficiently slow, so that fast typists could not cause the hammers on old manual typewriters to stick. See, e.g., Paul A. David, Clio and the Economics of QWERTY, 75 Am. Econ. Rev. 332 (1985). The Dvorak keyboard developed in the 1930s is usually touted as an example of a superior product which nonetheless failed to catch on. Some recent historical research has cast doubt on the technical superiority of the Dvorak keyboard, however. See S.J. Liebowitz \& Stephen E. Margolis, Network Externality: An Uncommon Tragedy, 8 J. Econ. Persp. 133 (1994); S.J. Liebowitz \& Stephen E. Margolis, The Fable of the Keys 33 J.L. \& Econ. 1 (1990).

17 Michael L. Katz \& Carl Shapiro, Network Externalities, Competition, and Compatibility, 75 Am. Econ. Rev..424 (1985). This is significant for our purposes. Even if one is inclined to agree with some critics that network externalities are relatively rare, see S.J. Liebowitz \& Stephen E. Margolis, Network Externality: An Uncommon Tragedy, 8 J. Econ. Persp. 133 (1994); John E. Lopatka \& William H. Page, Microsoft, Monopolization, and Network Externalities: Some Uses and Abuses of Economic Theory in Antitrust Decision Making, 40 Antitrust Bull. 317 (1995), the Internet is clearly one case in which such factors do have a role to play.

On the other hand, there are negative as well as positive externalities associated with increasing use of the Internet, just as there are with the telephone network. For example, increased usage may mean increased network congestion, slowing the response time of the networkSee Bailey, supra note _, at 264. 
of telephone networks is one. To be sure, there are private "online service providers" (such as Compuserve and America Online) who offer information services only to their members. But even these privately-owned services have been forced to offer Internet access to their subscribers in order to remain competitive. ${ }^{18}$ While the desirability of a unified network may seem obvious, it is a fact which distinguishes the Internet (and the telephone network) from most consumer products. No one would seriously argue, for example, that the optimal number of types of furniture or food was one. Generally, our market economy is premised on diversity of goods, which enables consumers to select the product most suited to their needs.

It does not necessarily follow from the need for a single network that one company (or government or group) must own the entire Internet. Indeed, the Internet is currently "owned" by a decentralized combination of phone companies, Internet service resellers ("Internet service providers" and "online service providers"), corporations, universities, and governments. Each of these groups owns a small piece of the physical cabling and interface software that makes up the Internet. But the Internet can exist in this distributed condition only because each of the participants has agreed -- expressly or impliedly -- to a set of protocols that allow them to read and pass through messages sent by other participants. ${ }^{19}$ Without such voluntary interconnection between members, the communications functions of

18 There are also networks which do not use TCP/IP, and therefore are not connected to the Internet. An example is Intelink, used by the U.S. intelligence community for secure communications. But this is a special case, intentionally designed to be different from the norm precisely in order not to communicate with others. See Froomkin, supra note , at 25 .

19 Within the TCP/IP umbrella are a variety of standards governing particular forms of communication. Networking standards for basic forms of Internet communication include SMTP (the "simple mail transfer protocol," which governs the exchange of ASCII text), MIME ("multimedia Internet mail exchange," which allows the transfer of both text and graphics), nntp (the "newsnet news transport protocol," which relays Usenet newsgroups between participating sites), http (the "hypertext transport protocol," which allows movement within the World Wide Web), and Mbone (a real-time audio and video exchange standard). See generally A. Michael Froomkin,A Model of International Law and Societ)(working paper 1995). 
the Internet (including recent proposals for Internet-based telephone service) ${ }^{20}$ wouldn't work, at least not on the same basis they do today. ${ }^{21}$ Neither would most of the information service products that have sprung up, since they are based on "spiders" or other "bots" that crawl the World Wide Web between multiple sites collecting dałă.

\section{B. Compatibility Factors}

20 On Internet telephony, see, e.g., Peter H. Lewis, Free Long-Distance Phone Calls! (Multimedia Computer, Modem, Software and Internet Connection Extra, N.Y. Times, Aug. 5, 1996, at C1, C6; Standards-Based Communications Over the Internet 2 Online Bus. Today\#3 (March 25, 1996), available from obt@ hpp.com.

21 See Francois Bar, Michael Borrus, \& Richard Steinberg, Interoperability and the NII: Mapping the Debate, 4 Info. Infrastructure \& Pol. 235, 236 (1995). The early history of the telephone industry provides an instructive analogy. In the early days of telephony, there was no central "phone company." While Bell's initial telephony patents gave him an early edge, by the 1890s Bell had numerous competitors. Thus, telephone networks started out as private local companies offering connection within a very limited service area. Most of these small companies agreed to interconnect with each other, but the largest national telephone company (Bell) refused to interconnect with its rivals. Forced to choose which of two competing networks to belong to, most consumers chose the larger, and Bell Telephone acquired nearly $90 \%$ of the market in the first two decades of the century. See Roger G. Noll \& Bruce M. Owen, The Anticompetitive Uses of Regulation: United States v. AT\&T, in The Antitrust Revolution291-94 (J. Kwoka \& L. White eds, 1989).

It is not at all obvious that the same thing could never happen on the Internet. In 1994, the CIX group threatened to shut down the free exchange of information, proposing to pass on messages only for other members of the group who paid a $\$ 10,000$ annual fee. And various proposals to exclude groups from the Internet would have a similar effect of breaking the implied agreement on message exchange. See Mark A. Lemley, Shrinkwraps in Cyberspace, 35 Jurimetrics J. 311, 321 (1995). An Internet without user agreement on protocols would look much like the telephone system throughout most of this century -- a centralized communications network controlled by one company.

22 A "bot" is Internet slang for a small software program (more formally, a "script") that is self-executing, and performs various functions on the Internet. Thus, "bots" on the Internet act like robots would in the real world, performing certain pre-programmed tasks automatically. A spider is a form of bot that resides on the World Wide Web and accesses various Web pages, compiling certain information by "crawling" from Web site to Web site and cataloguing what it finds. Various information services based on spiders are among the applications programs now available for use on the Internet. For more background on bots in general and spiders in particular, see Andrew Leonard,Bots are Hot, 4.04 Wired 114 (April 1996). 
This leads us to a second, related factor pushing the Internet towards standardization: the value of product interoperability. ${ }^{23}$ Just as communication in a network composed of privately owned pieces requires horizontal interconnection between those pieces, making effective use of that network requires that consumers and software developers be able to plug their products into the Internet and have them work. This "vertical compatibility" requirement is quite common in a variety of industries. An example of such a vertical interconnection externality is the design of electric power plugs on household appliances. An electric plug is useless unless it connects firmly to a wall electrical outlet. Thus, the design of electric plugs is significantly constrained by the design of wall outlets (and vice versa). In the United States, most plugs -- and most outlets -- have either two or three prongs. While it is possible to buy an adapter to switch from three to two prongs if necessary, and theoretically possible to build and sell adapters for plugs of six, eight, or twenty-three prongs, the existence of so many twoand three-prong outlets provides a strong incentive to new plug manufacturers to build their plugs to fit the existing outlets.

A similar thing happens with software, though the connections (and thus the available "adapters") are much more complex than electrical outlets. To use a computer, a customer needs the computer itself, which must be compatible with the microprocessor and any necessary peripheral hardware (such as printers, keyboards, monitors and modems), an operating system, which must be compatible with the microprocessor, and applications programs, which must be compatible with the operating system. ${ }^{24}$ These compatibility

23 In this paper I treat the terms compatibility and interoperability as equivalent. Technically this is inaccurate, and indeed industry representatives have fought over the meaning of these terms. See Joseph Bailey, Lee McKnight, \& Paul Bosco, The economics of advanced services in an open communications infrastructure: Transaction costs, production costs, and network externalities, 4 Info. Infrastructure \& Pol. 255, 257 (1995).

24 For a more detailed description of these components, see Peter S. Menell, An Analysis of the Scope of Copyright Protection for Application Programs41 Stan. L. Rev. 1045 (1989). 
requirements impose significant constraints on hardware and software developers. For example, today a single company (Microsoft) has sold more than $80 \%$ of the personal computer operating systems in existence in the market. Other companies, such as Apple, IBM and Sun, have $10 \%$ or less of the installed base of operating systems. ${ }^{25}$ A software developer writing a new applications program obviously will want to write it to be compatible with the current Microsoft operating systems, since the potential market for those systems is much larger. As a result, most applications programs written today are written for the dominant Microsoft operating system. This fact in turn influences consumers deciding to buy a new computer system. They, too, are more likely to buy a Microsoft system, since they know that most current and future applications are likely to work on that system, rather than a competing system. ${ }^{26}$ The effect is cyclical -- once established, dominant operating systems are very hard to dislodge, because people tend to write for and buy from the dominant manufacturer.

Analogous compatibility effects are evident in many Internet software markets. Because Internet software at base is selling connectivity, it must of course be compatible with the basic protocols governing transmission of information on the Internet. ${ }^{27}$ In addition,

25 See, e.g., My Way or the Highway, N.Y. Times, Mar. 18, 1996, at C5 (Microsoft Windows "currently controls more than $80 \%$ of the operating systems market. Mac OS accounts for more than $7 \%$, as does OS/2."); Evan Ramstad, Browser Battle Has High Stakes, Austin Am.-Statesman, Mar. 18, 1996, at D8 (Microsoft has a $90 \%$ share in operating systems).

26 This problem is ameliorated to some extent if applications program developers can "port" their programs to different operating systems. However, such translation is often difficult, and operating system companies may place legal or technical obstacles in the way of translation efforts. See, e.g., Atari v. Nintendo, 975 F.2d 832 (Fed. Cir. 1992); Sega of America v. Accolade, Inc., 977 F.2d 1310 (9th Cir. 1992) (both considering copyright issues arising from efforts of dominant video game box manufacturers to prevent game designers from writing games that would work on multiple systems); $c f$. United States v. Microsoft, Inc., 159 F.R.D. 318 (D.D.C. 1995), rev'd on other grounds 56 F.3d 1448 (D.C. Cir. 1995) (considering similar allegations made against Microsoft).

27 Indeed, the importance of precise compatibility is much greater in the computer and Internet contexts than in other types of markets. Compliance with technical specifications must be exact, because computer systems are notably intolerant of mistakes. As David Post puts it, "you can't 'almost' be on the Georgetown University LAN or America Online -- you are either transmitting LAN- or AOL-compliant messages or you are not." Post, supra note , at $\mathbb{\text { II } 2 0 .}$ 
Internet software such as electronic mail programs and Web browsers must be compatible with a computer operating system -- frequently more than one operating system, if the consumer is a business whose servers run one system and whose client computers run another. ${ }^{28}$ Finally, programming on the World Wide Web is done in new, often proprietary computer languages $^{29}$ (such as Sun's Java, and Microsoft's Visual Basic, and the publicdomain HTML) or using authorial software (such as InContext Spider) which layers over such a language. Each of these languages must be compatible with both the host operating system and the Web browser consumers are most likely to use to interact with it. And in turn, the new forms of "Web applications software" that are starting to develop -- search engines like Lycos, Altavista, or Yahoo, for example -- must be able to work with as many Web programming languages as possible, so that they can carry out an efficient search. Thus, Web browsers and programming languages are driven to standardization for the same reasons that PC-based operating systems are -- developers and consumers are both likely to gravitate towards the system they think will come to dominate, helping ensure that that system does in fact become dominant. Economists refer to this as the "tipping" effect.

\footnotetext{
28 As of this writing, the market for higher-end server operating systems appears to be more competitive than the market for PC-based operating systems. Competitors in that market include Microsoft, Novell, IBM, DEC, and a number of companies marketing a version of the Unix operating system.

29 There has been considerable debate over whether languages can be copyrighted. See Lotus Dev. Corp. v. Paperback Software, 740 F. Supp. 37 (D. Mass. 1990); Branscomb \& Kahin, supra note _ , at 18; Pamela Samuelson, Computer Programs, User Interfaces, and Section 102(b) of the Copyright Act of 1976: A Critique of Lotus v. Paperback, 55 L. \& Contemp. Probs. 311, 334-35 n.109 (1992) (collecting sources). On the other hand, there seems no question at this point that a new and nonobvious improvement in computer langauges could be patented, though perhaps the entire syntax of the language could not be. See generally Bar et al., supra note _, at 247-48; David O'Brien \& Mark A. Lemley, Encouraging Software Reuse, 49 Stan. L. Rev.__ (forthcoming 1997).

30 See, e.g., Joseph Farrell \& Garth Saloner, Competition, Compatibility and Standards: The Economics of Horses, Penguins, and Lemmings, in Product Standardization and Competitive Strategy 1 (H. Landis Gabel ed. 1987); David McGowan, Regulating Competition in the Information Age: Computer Software as an Essential Facility Under the Sherman Act 18 Hastings Comm/Ent. L.J.___ (forthcoming 1996).
} 
This doesn't necessarily mean that there will be only one Web browser, much less one search engine, on the Web of the future. But it does mean that Web browsers and search engines will be successful only to the extent that they are compatible with the dominant programming language in use on the Web, and with the dominant operating system that runs users' computers.

\section{Resource Commitments}

Finally, a third factor inclines computer markets towards standardization. As consumers of existing software products commit resources to those products, they become disinclined to move from their current program to a competing one. These resource commitments are of two basic types. First, using a new program requires learning. As people grow more comfortable with an existing program, they are more and more reluctant to switch to a new program. This "convenience" externality may not seem like a very powerful force, but the collective inertia may actually be quite substantial. ${ }^{31}$ Second, people not only invest time in learning a new program, but over time they create documents and store data readable by that program. For example, users who have created a huge database in an existing program are unlikely to want to purchase a new program if the new program can't access their data. Thus, unless there is a way to translate data from old to new programs, old programs may retain a captive audience among the installed base of users long after the programs themselves have become obsolete. ${ }^{32}$ Both effects result in what contemporary economists call "path

\footnotetext{
31 See supra note _ (discussing the QWERTY typewriter keyboard, often cited as an example of this effect); Dratler, supra note __, at 706 ("This investment of time and energy in training and development has locked me into WordPerfect 5.1 as surely as if I had signed a pledge in blood to be its loyal user forevermore. I would no more think of converting to Microsoft Word or some other new word processing program, and thereby losing all of my investment in macros and training, than I would consider doing all of my professional writing henceforth in Swahili.").

32 This is part of what was at issue in the Lotus v. Borland case. Lotus Dev. Corp. v. Borland Int'l, 47 F.3d 809 (1st Cir. 1995), aff'd by equally divided court 116 S. Ct. 804 (1996). Lotus sought to prevent Borland, the developer of a subsequent and much improved spreadsheet program, from selling a program which read Lotus 1-2-3 macros developed by users of the program. Had Lotus been able to do so, the effect would have been to give existing Lotus users a powerful incentive not to switch to Borland's spreadsheet. On the externality problems that would result if the law failed to allow such a "migration path" between products, see Marci A.
} 
dependence," a tendency to make decisions about future behavior which are constrained by past choices ${ }^{33}$

These resource commitments also have their analog in the Internet context. Switching Web browsers or electronic mail programs may involve the loss of stored addresses or "bookmarks," as well as cached data, though the level of commitment to such resources has so far been lower than in the rest of the software industry. ${ }^{34}$ More significantly, as the number of Web pages grows exponentially, so does the installed base of Web programmers using existing programming languages. The development of new browsers or programming languages that do not interoperate with the existing generation would likely prove problematic, since the cost of everyone currently on the Web switching to a new program is probably substantial. On the

Hamilton \& Theodore M. Sabety, Computer Software Copyright Terminology and its Unintended Externalities (working paper 1996).

33 See Mark J. Roe, Chaos and Evolution in Law and Economics, 109 Harv. L. Rev. 641 (1996). Roe explains path dependence using an example of a road which was originally curved in a certain direction because of constraints that existed at the time (in his example, avoiding a den of wolves). Over time, the reason for the curve disappeared, but subsequent developments (widening and paving the road, buildings constructed around it, etc.) have reinforced the original curve, making it less likely that the curve will ever be straightened. The result, as Roe explains, is that "society, having invested in the path itself and in the resources alongside the path, is better off keeping the winding road on its current path than paying to build another. Occasionally, the path-dependent road becomes so costly that society rips it up and builds a new one." Id. at 643-44. See also Stanely M. Besen \& Joseph Farrell, Choosing How to Compete: Strategies and Tactics in Standardization, 8 J. Econ. Persp. 117, 118-19 (1994) ("network market equilibria often cannot be understood without knowing the pattern of technology adoption in earlier periods."); Peter Passell, Why the Best Doesn't Always Win N.Y. Times Mag, May 5, 1996, at 60, 61.

Path dependence should be distinguished from reliance on "sunk costs" in decision-making. Once an irreversible commitment has been made, it is rational to ignore the expenditure on that commitment in deciding a future course of action. Thus, if I have put down a $\$ 2,000$ deposit on a $\$ 20,000$ car, my decision on whether to buy that car should reflect the fact that it will cost me $\$ 18,000$ to do so, but should not otherwise be colored by the $\$ 2,000$ I have already spent. The $\$ 2,000$ is a sunk cost. By contrast, once I have chosen a car, that choice is likely to have a significant impact on where I have the car serviced. I am unlikely to sell my new car and buy another one simply because I want to use a particular service provider. The constraint that the purchase puts on my subsequent decision-making is what is meant by path dependence.

34 Some Web applications software, like search engines, do not involve substantial resource commitments from users, and therefore this factor does not apply to such software. Further, most Web browsers are quite easy to use, meaning that the learning curve effects are minor relative to programs like databases or spreadsheets. 
other hand, since the Web is growing so dramatically, the lock-in effect may be less powerful in the Internet software market than in other, more mature markets. Even if all current users of the Web have an incentive to remain with existing software, new users face no such constraint, and so might be induced to select a new program which is better ex ante. If the rapid growth of the Internet continues, these new users may overwhelm the users of the old standard, causing the old standard to be replaced over timé.

\section{Consequences}

All three of these factors point in a single direction -- towards a small set of standardized products with market durability that may significantly outlast the competitive superiority of the product. ${ }^{36}$ The nature of the Internet, and indeed of most computer software markets, is such that a single standard is likely to emerge as the dominant one at each of several levels of performance. ${ }^{37}$ The Internet is necessarily characterized by a single set of transmission protocols. As the market develops, it will probably also be characterized by a dominant Web programming language ${ }^{38}$ and a dominant Web browser. ${ }^{39}$ On the other hand,

35 Arguably this is what happened in the VCR market, where the growth in the number of VCRs allowed the VHS standard to quickly overwhelm its competitor Betamax, even though the latter had an early lead.

36 See Joseph Farrell, Standardization and Intellectual Property30 Jurimetrics J.35, 36-37 (1989).

37 At the same time, standardization effects may also produce pockets of resistance to the standard. Normally, these will be relatively insular groups which have adopted and clung to their own standard, long after the rest of the world has moved on. The British "drive-on-the-left" rule and the United States system of weights and measures are obvious examples of "local standards" that are inefficiently at odds with the prevailing world standard. See Robert H. Cooter, Decentralized Law for a Complex Economy: The Structural Approach to Adjudicating the New Law Merchant144 U. Pa. L. Rev.1643, 1687 \& n.106 (1996).

38 What that dominant programming language is today is unclear. Most text-based Web programming still takes place today using the public-domain HTML language. More advanced Web programming is gravitating to Sun's Java language. While Sun has some claim to own Java, there has been some recent work towards developing technology which would allow programmers to produce Java byte codes using non-Java programming languages. If this happens, it may be the Java virtual machine rather than the programming language itself which is standards-driven.

39 Today, Netscape's Navigator Web browser software controls $85 \%$ of the market for browsers, well ahead of its closest competitor, Microsoft's Internet Explorer. Ramstad, supra note _, at D8; Online Business Today, April 2, 1996 (available from obt@ hpp.com). Following well behind are at least 63 other competing browsers. 
certain Internet applications product markets, such as the market for search engines, do not exhibit these characteristics, and so may remain competitive indefinitely.

To the extent that more than one product does share the market in these standardized industries, it will almost certainly be because the products are compatible with each other, or at least with the dominant up- or downstream product. ${ }^{40}$ The importance of interoperability in this market is evident in all three of the reasons described above. The Internet itself will not run unless protocols exist to interconnect different parts with each other, just as telephone networks must be interconnected according to a uniform set of standards. ${ }^{41}$ Products designed to work on the Internet will not be marketable unless they can easily connect to the Internet itself and, to a lesser extent, to each other. And new generations of products will work at a significant disadvantage unless they are compatible with prior generations, so that the installed base of consumers can transfer data smoothly from one product to the next.

See http://www.browserwatch.com/browsers.html. The Web programming market is also standardized; most text-based Web programming is done using some version of the public-domain Hypertext Markup Language, or HTML, and most Web pages that offer "applets" for automatic downloading are written in Sun's Java language.

40 For example, multiple applications programs such as WordPerfect and Microsoft Word can coexist in the software industry because both are compatible with the dominant Microsoft operating systems.

41 See FCC Rules, Part 68 (governing electronic products which may interfere with communications).

42 As economist Garth Saloner has argued, this installed-base phenomenon is to some extent selfperpetuating. He writes:

Because of the compatibility and network benefits, all else equal, a new user prefers a vendor with a larger total installed base of users. Thus installed bases have a tendency to be selfperpetuating: they provide the incentive for the provision of products (software and hardware) that is [sic] compatible with that in the installed base which in turn attracts new users to the installed base, further swelling its ranks and increasing the incentive for the provision of even more complementary products.

Garth Saloner, Economic Issues in Computer Interface Standardization, 1 Econ. Innov. \& New Tech. 135, 140 (1990). 
To a significant extent, interoperability -- and thus the nature of standardized markets - is determined by the rules of intellectual property law. If everyone was free to copy and use a dominant market standard, the fact that such standards existed would not prevent competition in that market. Competitors would simply copy the standard from its original developer, and sell identical (or perhaps improved) products based on that standard. But free copying of computer programs that have become standards has certain undesirable consequences as well. For example, the ease of imitation of software in the absence of a legal regime preventing such copying suggests that a market for operating systems where copying was permitted would be competitive -- firms would sell programs at their marginal cost of copying, probably for less than $\$ 1$ each. However, this low marginal cost would prevent the first developer of an operating system from recouping its initial fixed costs of designing and producing the program, and would therefore discourage subsequent developers from producing new systems. It is this "public goods" problem which justifies intellectual property protection for software 43

The fact that intellectual property law allows a company to prevent the copying of software means that the same factors which drive an industry towards a single standard may also drive that industry towards monopoly. ${ }^{44}$ Specifically, while companies owning intellectual property in a potential standard can if they wish license it freely, they will not do so if they believe that the result of their refusal will be a standards competition which they will win. ${ }^{45}$ Conversely, to the extent that access to software standards is open, competition is

43 See Peter S. Menell, Tailoring Legal Protection for Computer Software, 39 Stan. L. Rev. 1329 (1987); Pamela Samuelson et al., A Manifesto Concerning the Legal Protection of Computer Programs, 94 Colum. L. Rev. 2308 (1994).

44 See Bar et al., supra note _-, at 242-43.

45 See Henry H. Perritt Jr., Law and the Information Superhighway 349 (1996). This explains why, for example, Bell Telephone refused to interconnect its new telephone network with competing networks in the early part of this century. See Noll \& Owen, supra note __, at 291-94. 
possible even within a standardized environment. For the remainder of this article, I will assume that the standards I discuss are at least potentially the subject of intellectual property rights of some sort, and thus capable of being owned by a single firm.

\section{The Effects of Standardization}

\section{A. De Facto Standards}

Legal and economic doctrine has had some experience dealing with industries in which the optimal number of firms is one. Called "natural monopolies," these industries are generally characterized by extremely high start-up costs and relatively low marginal costs, with the result that average total cost is declining over the entire range of market demand. ${ }^{46}$ This situation is graphically represented in Figure 1.

[Insert Figure 1 here]

Economic theory and experience with such industries offer two important lessons about natural monopolies. First, the end result of competition in a market characterized by natural monopoly will be a single victorious firm which drives out its competitors. Because the fixed initial investment required to enter such a market is so high, and the marginal cost of additional production so low, firms have an incentive to cut prices in order to expand their market share over the entire range of market demand, since doing so reduces their average total costs. If two firms are competing in such a market, they will engage in a price war until one has captured the entire market (and thus minimized its average total cost), ${ }^{47}$ or at least

46 A commonly used example of a natural monopoly is the market for local distribution of electric power. See Richard J. Pierce \& Ernest Gellhorn, Regulated Industries (1994). Note that it does not follow from this that either the production or the long-distance transmission of electric power are natural monopolies, as regulators erroneously assumed for many years. See Symposium: Antitrust, Joint Ventures, and Electric Utility Restructuring, 64 Antitrust L.J. 267 (1996) (discussing changes in economic analysis of electric power markets).

47 Consumers may also hold off purchasing new technology until they are sure it will be accepted. This is arguably what is occurring with recordable digital audio media such as Sony's Mini Disc System and Philips' Digital Compact Cassette. See My Way, supra note __, at C5. 
until the winner has bought out the loser. Companies build duplicative networks in such a market only to engage in rent-seeking: they believe that they will be able to capture the full market and thus extract monopoly rents over a significant time period.

Second, since the result will be monopoly in any case, competition in natural monopoly markets is wasteful to some extent. While the lure of monopoly power may induce more than one firm to invest in the fixed assets needed to compete in this market, only one firm can succeed, and the assets of the others will go to waste (at least if they are not readily convertible to other uses). ${ }^{48}$ As an example, imagine three firms each building their own electric power distribution networks in a single city, and competing for customers. It is more efficient for one firm to distribute electric power to all customers at the local level, and the result of this period of competition will be two extra sets of (unused) local power distribution networks.

However, competition to set the standard for the next generation of products may still serve a valuable purpose if it drives innovation in the market. A competition for a natural monopoly position between three firms with identical technology and cost structure serves no valid purpose; consumers should be indifferent between monopolists in this situation. But if companies competing to set an industry standard are offering different technology, this competition may serve a temporary market-disciplining purpose, allowing consumers to choose the best technical standard on a one-time basis. Similarly, consumers rationally should prefer to choose as their monopolist a firm with a lower cost structure than its rivals, all other things being equal. Even though the victor in such a competition will likely be able to price above cost, choosing a firm with a lower cost structure should enhance both social and consumer welfare, since even assuming monopoly pricing part of that cost advantage will be reflected in lower prices and increased production. See Figure 2. Further, even if the price is

$48 C f$. Besen \& Farrell, supra note _, at 119 (rent-seeking will dissipate much of the monopoly profits to be gained from standard-setting). 
not lower, the cost savings on the part of the more efficient producer reflect an allocative efficiency gain.

[insert Figure 2 here]

The Internet software industry is not a natural monopoly. ${ }^{49}$ The most important difference is that the cost of initial fixed investment in computer software, while high relative to the marginal cost of producing copies of computer programs (which is near zero today), is still low in an absolute sense. Capital markets can and do provide financing for those interested in developing new software programs, meaning that initial barriers to entry are much smaller than in traditional natural monopoly markets. ${ }^{50}$ As a result, both entry and innovation are much more common in software markets than in electric power distribution markets.

Nonetheless, the standardization effects described above have an impact analogous in important ways to that of a natural monopoly. Specifically, computer markets with strong standardization tendencies, such as the personal computer operating systems market or the market for Web programming languages, will generally converge on a single product standard over time. Assuming the existence of intellectual property rights in software, but no other government intervention in the software market, markets such as that for PC operating systems will naturally tend towards a "de facto" standard -- the victor in the marketplace..$^{51}$ Further, for the reasons identified in the last section, that single product standard is likely to be

49 For an examination of this issue in some detail, see David McGowan, Regulating Competition in the Information Age: Computer Software as an Essential Facility Under the Sherman Act, 18 Hastings Comm/Ent. L.J.__ (forthcoming 1996).

50 The cost curve for computer software markets is also distorted from the stylized view presented in Figure 1 because of the existence of intellectual property rights in software.

51 Indeed, historical evidence in the PC operating systems market suggests that that is precisely what happened. Microsoft's MS-DOS operating system (and its subsequent iterations, Windows and Windows '95) currently dominate that market. 
highly durable and self-reinforcing, as consumers and product developers focus their attention on the dominant standard to the exclusion of all others?.

This self-reinforcing effect may continue between product generations. The market power of the entrenched standard-setter is sometimes sufficient to allow that company to dictate the next generation standard as well. ${ }^{53}$ In part this is based on consumer expectations: consumers assume that the largest company in the industry will set the standard, and if enough consumers make the same assumption, it becomes a self-fulfilling prophecy. ${ }^{54}$ However, this effect may be counterbalanced to some extent if the market leader from a prior product generation is significantly encumbered by having to provide backwards compatibility with its earlier products. Over time, the necessity of backwards compatibility may make the leader's product larger and harder to change, rendering it vulnerable to "leapfrogging" by competitors who face no such restriction.

An example of these effects is the contemporary market for software operating systems. Microsoft has dominated this market since the early 1980s, first with MS-DOS and then with Windows and Windows 95 software. Both Windows and Windows 95 have been delayed and have suffered performance problems occasioned by Microsoft's desire to make them compatible with early versions of MS-DOS. At the same time, Microsoft's continued

52 This durability is also evident in the PC operating systems market, where Microsoft's products have been dominant for 15 years, despite their apparent technical inferiority and despite the rapid change that has characterized other parts of the computer industry. The durability of this market power results from high barriers to effective entry -- competitors may enter the market, but they are unlikely to be able to dislodge the market leader. Because of these barriers, it is also reasonable to assume that the threat of entry will not serve a serious market-disciplining effect once a standard has been set. But see Harold Demsetz, Why Regulate Utilities?, 11 J.L. \& Econ.55 (1968) (arguing that natural monopolies do not exist).

53 See Farrell, supra note _, at 39-40 (citing example of pre-breakup AT\&T, which set multiple generations of telecommunications standards with relative impunity).

54 A number of commentators have alleged that Microsoft has taken advantage of this effect in the operating systems market by using product preannouncements (or "vaporware") to deter customers from buying competitive products. See, e.g., [cite], 40 Antitrust Bull._(1995). 
dominance in the market is largely attributable to that compatibility between product generations.

Of course, the need for backwards compatibility should similarly encumber any other firm that can make its products compatible with the prior standard. Thus, if a system is "open" rather than proprietary, all competitors will face the same demand for backwards compatibility. Alternatively, if closed systems have competed with one another in the past, the owners of both systems may face a demand for backwards compatibility by users of those systems. Thus, Apple Computer has significant incentives to make its new operating system compatible with its older ones, so as not to "strand" the minority of consumers who have used Apple systems in the past. But Apple's constraints of this nature are less than Microsoft's, because its installed base of users is less. And a new entrant will face no such constraints.

Even the development of moderately better competitive products is unlikely to dislodge a de facto standard once it has been established. Only a dramatic improvement -- a leapfrogging product -- will force consumers and developers to disregard the switching costs and move to the new product. ${ }^{55}$ In turn, that new product is likely to become the de facto standard, after a period of competition and uncertainty. In the Internet software market of 1996, standards competitions are occurring in virtually every market segment. Microsoft and Sun are competing to set the standard among Web programming languages, ${ }^{56}$ Microsoft is competing with an Apple-Silicon Graphics consortium to set the standard for 3-D graphics

55 See Farrell \& Saloner, supra note _..

56 See, e.g., Michael Neubarth, Microsoft Declares War, Internet World, March 1996, at 36, 38-39 (Microsoft's Visual Basic Script, a revised version of the Visual Basic programming language, to be released as a Web programming language; Microsoft's Internet Studio will compete with Adobe's Acrobat in a different segment of the same market). Interestingly, Microsoft appears to be playing both sides of the fence on Web programming standards, licensing Sun's Java and JavaScript at the same time it plans a new product to compete with them. See id.; John Markoff, Java Backers Taking Aim at Microsoft's Dominance, N.Y. Times, Dec. 4, 1995, at _. This may be a function of Microsoft's vertically integrated position in the industry, which will make it reluctant to risk browser market share in order to push its own programming language. See infra note __ (discussing browser market share battles). 
presentations, ${ }^{57}$ Microsoft and Netscape are competing to set the standard for Web browsers, ${ }^{58}$ and Microsoft (with its partner Visa) and Netscape (with its partner Mastercard) have tentatively agreed on a joint standard for electronic payment. ${ }^{59}$ Further, certain of these standards compete among themselves: it doesn't do much good to win the competition over the two-dimensional graphics programming language if the industry rapidly switches to 3-D graphics instead. And underlying all of this Internet standards competition is continuing competition among hardware providers, server operating systems, and Internet and online access providers, all of which impact Internet software marke€£.

Such competition between potential standards is not as inefficient in the computer industry as it is in traditional natural monopoly markets. This is true both because the absolute level of fixed investment (and thus the potentially wasted resources) is far lower than in traditional natural monopoly markets, and because the threat of competition may spur innovation on the part of a standard-setter. Nonetheless, competition between potential standards does have troubling economic effects. In particular, the "tipping" phenomenon means that consumers using one product may end up being stranded in a dead-end standard as the market moves en masse to the prevailing standard. This was the fate of those who owned the Betamax VCR in the early 1980s, as the open VHS standard prevailed. While for a time it was possible to find stores that sold or rented Betamax tapes, that is no longer true.

57 See Charles Platt, They Render Unto Bill, 4.07 Wired 114, 117 (July 1996) (describing such competition).

58 See, e.g., Peter H. Lewis, Microsoft Gets a Big Boost on Internet, N.Y. Times, Mar. 13, 1996, at C1 (Microsoft convinced America Online to bundle its Internet Explorer Web browser software with AOL membership, rather than Netscape's competing Navigator software); Lewis, supra note _, at C6 (Microsoft to give away its Explorer software in an effort to compete with Netscape's Navigator); Michael Neubarth, Microsoft Declares War Internet World, March 1996, at 36 (same).

59 See, e.g., John Markoff, Microsoft Joins Visa to Propose a Standard for On-Line Paying, N.Y. Times, Sept. 28, 1995, at C1, C20; Jeff Pelline \& Michelle Quinn, Mastercard, Visa Accord on Internet, S.F. Chron., Feb. 1, 1996, at A1; Jessie ScanlonDecrypting the Next Hot IPO, 4.04 Wired 74 (April 1996).

60 Neubarth, supra note __, at 39-41. 
Consumers who bought the Betamax (or worse, compiled a library of Betamax tapes) were eventually forced to adopt the prevailing standard. ${ }^{61}$ A similar tipping effect towards a new Web programming language (and new, compatible browsers) could "strand" both older Web pages and browsers unable to read the new pages?

\section{B. Standard-Setting Organizations}

The problems with "winning" and "losing" standards in the computer industry are generally traceable to the fact that the standards are incompatible, forcing consumers and developers to choose between them. ${ }^{63}$ The result is that standards have a "winner-take-all" quality, rewarding the developer of a new standard by giving him the full value of the standard itself, and not just the value of his contribution. ${ }^{64}$ This result is inefficient. The network externality effect (the fact that everyone benefits from broad participation on the network) suggests that network goods optimally should be priced as low as possible, to allow

\footnotetext{
61 See, e.g., Cusumano et al.,supra note _..

62 Indeed, there is some evidence that this has already happened to older browsers, such as Lynx. Of course, stranded products are not uncommon in a variety of markets. Replacement parts and service for old products no longer in production may be difficult or impossible to come by, for example.

63 See supra notes _____ and accompanying text.

64 See David Friedman, Standards as Intellectual Property: An Economic Approach, 19 U. Dayton L. Rev. 1109 (1994). Of course, in practice most standards competitions are not won absolutely, and minority products (like the Apple operating system) do continue to exist. Nonetheless, it is clear that the benefits to becoming the dominant standard-setter are substantial. But cf. Gifford, supra note _, at 642 (suggesting that this fringe competition makes the network externalities argument less important).
} 
widespread adoption of the standard.65 A proprietary standard owned by a single company which can set whatever price it wants does not seems the best way to achieve this gøal.

One possible solution to the Internet standardization problem is to make the competing standards interoperable. If people can switch back and forth between competing versions of what is essentially the same standard, perhaps society can capture the benefits of competition without wasteful duplication of effort, and without stranding consumers who make the wrong choice. ${ }^{67}$ There are at least three different possible ways such interoperable standards could be achieved 68

First, one might interpret the intellectual property laws to achieve this effect. In the particular context of the computer industry, a single company can establish a de facto standard only if it is able to exclude others from using that standard. Absent intellectual property rights in the software constituting the standard, the would-be monopolist would have no way to prevent others from selling the standard as well. Therefore, one possible solution to the de facto standards problem would be to preclude companies with a dominant market position

65 See Joseph Farrell, Arguments for Weaker Intellectual Property Protection in Network Industries, Berkeley Program in Law and Economics working paper 94-11 (1994) ("when network effects are present, each user deterred by a price above cost not only loses the benefit of the innovation for himself but also reduces the benefit to all those who do adopt. So a given reduction in demand is more harmful when network effects are important.").

66 Nor does it seem necessary to encourage the production of future works of intellectual property. While this is the purpose behind providing intellectual property protection, the winners of standards competitions receive a windfall that is far greater than what intellectual property normally gives as an incentive to invention.

67 Such group standard-setting is common in the computer hardware industry. Another more recent example is the market for digital video discs, where competing groups (Sony-Philips and Toshiba-Matsushita) offering incompatible standards recently agreed to use a single compatible format incorporating elements from both products. See My Way, supra note _, at C5. There is some recent empirical evidence to suggest that open, group-set standards produce cost savings over proprietary standards. See Bailey et al., supra note _, at 27172.

68 See Lewis M. Branscomb \& Brian Kahin, Standards Processes and Objectives for the National Information Infrastructure, in Brian Kahin \& Janet Abbate, eds., Standards Policy for Information Infrastructure 3, 5-9 (1995) (modelling competitive, cooperative, and regulatory models of standard-setting). 
from enforcing their intellectual property rights in the standard. ${ }^{69}$ Such a scheme might be workable, though it would require careful attention to the problem of ensuring that intellectual property owners retained adequate incentive to develop software in markets characterized by standardization. Alternatively, intellectual property law could provide a built-in mechanism to achieve interoperability with an industry standard. Copyright and trade secret law currently have such a mechanism -- they both permit reverse engineering in at least some circumstances $^{70}$-- but patent law does not. ${ }^{71}$ Perhaps more to the point, federal

69 For cases adopting just such a proposal, see Radio Telefis Eireann v. Commissioner, Cases C-241/91 \& C242/91 (E.C.H. April 6, 1995) (information protected by copyright must be licensed on reasonable terms if it is indispensible to the ability of others to compete in the field); Ilene Knable Gotts \& Howard W. Fogt, Jr., Clinton Administration Expresses More than Intellectual Curiosity in Antitrust Issues Raised by Intellectual Property Licensing, 22 AIPLA Q.J. 1, 21-22 (1994) (discussing Justice Department's requirement that Borland agree not to assert its intellectual property rights against Lotus, as a condition of the Borland/AshtonTate merger). See also Matthew P. Larvick, Questioning the Necessity of Copyright Protection for Software Interfaces, 1994 U. Ill. L. Rev. 187 (endorsing such a limitation); but see Kenneth W. Dam, Some Economic Considerations in the Intellectual Property Protection of Software, 24 J. Legal Stud. 321 (1995) (suggesting that strong property rights are appropriate in such a case). One court has expressly done this, holding that access codes which have become the de facto industry standard cannot be copyrighted under the scenes a faire doctrine. See Mitel v. Iqtel, 896 F. Supp. 1050 (D. Colo. 1995). To some extent, this was also one of the issues at stake in Lotus Dev. Corp. v. Borland Int'l, 49 F.3d 807 (1st Cir. 1995). See id. at 821 (Boudin, J., concurring).

70 See, e.g., Unif. Trade Secrets Act $§ 1$, comment:

Proper means [for discovering a trade secret] include ... [d]iscovery by "reverse engineering", that is, by starting with the known product and working backward to find the method by which it was developed.

In the copyright context, courts and commentators endorsing copying to achieve interoperability as a fair use include Lotus Dev. Corp. v. Borland Int'l, 49 F.3d 807, 817-18 (1st Cir. 1995) (Boudin, J., concurring); Atari Games Corp. v. Nintendo of America, 975 F.2d 832, 843-44 (Fed. Cir. 1992); Sega, Inc. v. Accolade, 977 F.2d 1510, 1527-28 (9th Cir. 1992); Vault v. Quaid, 847 F.2d 255, 270 (5th Cir. 1988); DSC Communications v. DGI Technologies, _ F.3d _ (5th Cir. 1996); Bateman v. Mnemonics, Inc., _ F.3d _ (11th Cir. 1995); Mitel Inc. v. Iqtel Inc., No. 95-B-900 (D. Colo. Aug. 23, 1995); Jonathan Band \& Masanobu Katoh, Interfaces on Trial (1995); Julie Cohen, Reverse Engineering and the Rise of Electronic Vigilantism: Intellectual Property Implications of "Lock-Out" Technologies 68 S. Cal. L. Rev. 1091 (1995); Dennis S. Karjala, Copyright Protection of Computer Documents, Reverse Engineering, and Professor Miller, 19 U. Dayton L. Rev. 975, 1016-18 (1994); David A. Rice, Sega and Beyond: A Beacon for Fair Use Analysis . . At Least as Far as It Goes, 19 U. Dayton L. Rev. 1131, 1168 (1994). But see Apple Computer v. Franklin Computer, 714 F.2d 1240, 1253 (3d Cir. 1983); Anthony Clapes, Confessions of an Amicus Curiae: Technophobia, Law and Creativity in the Digital Arts, 19 U. Dayton L. Rev. 903 (1994); Arthur Miller, Copyright Protection for Computer Programs, Databases, and Computer-Generated Works: Is Anything New Since CONTU?, 106 Harv. L. Rev.977, 1029-32 (1993). 
telecommunications law in effect modifies intellectual property law by requiring the interconnection of telecommunications devices on reasonable terms. ${ }^{72}$ A full elaboration of possible changes to the intellectual property laws is beyond the scope of this paper.

A second possibility is that the government might identify and set the appropriate standard, and compel all participants in the market to comply with those standards. The government does do this sort of thing from time to time. ${ }^{74}$ For example, the Federal Communications Commission sets standards for interconnection between telephone networks, and standards which govern the use of products which might interfere with broadcast

At least some Internet software companies are building standards-compatible products through reverse engineering. For example, Natural Intelligence Corp. apparently "clean-roomed" Sun's Java system from publicly available information in order to develop its Roaster product, a Macintosh-based programming environment for Java applets. See Apples and Beans, 4.04 Wired 145 (April 1996). But it is not yet clear that the permissible scope of reverse engineering under copyright law extends so far as to protect the use of material crucial to the standard in a final, competitive product.

71 See Michael A. Epstein, Standards and Intellectual Property, in Intellectual Property/Antitrust (P.L.I. 1993) (no restrictions on asserting a patent which controls a standard).

One might interpret the patent misuse doctrine as a rule compelling interoperability in limited circumstances. The problem with this approach is that Congress appears to have foreclosed in in 1988, when it passed the Patent Misuse Reform Act. That act added 35 U.S.C. $§ 271(d)(4)$, which provides that refusal to license a patent does not constitute patent misuse.

72 See Telecommunications Deregulation Act of 1996, 104th Cong., 2d Sess. (1996).

73 See Brief Amici Curiae of American Committee for Interoperable Systems and Computer \& Communications Industry Association in Support of Respondant in Lotus Dev. Corp. v. Borland Int'l, No. 942003 at 27-28 (U.S. Dec. 8, 1995) ("economists have demonstrated that in markets with strong network externalities, such as the market for software, the first comer reaps enormous competitive advantages from the establishment of a de facto standard interface specification. Copyright should not compound this "winner takes all" result by locking the gateway to competition."); but see David Friedman, Standards as Intellectual Property: An Economic Approach, 19 U. Dayton L. Rev. 1109 (1994) (arguing that standards deserve intellectual property protection in certain circumstances).

74 See Andrew Updegrove, Consortia and the Role of the Government in Standard Setting, in Kahin \& Abbate eds., supra note _, at 321. In this paper, I focus on mandatory government standards. The government may also act from time to time as a market participant, using its purchasing power to try to push a single standard in the market. See Howard S. Dakoff, Note, The Clipper Chip Proposal: Deciphering the Unfounded Fears that are Wrongfully Derailing its Implementation, 29 John Marshall L. Rev. 475, 482-84 (1996) (identifying one case where the government has done so). Such actions do not raise the same sorts of concerns as mandatory standards, at least where the government lacks monopsony power. 
communications. ${ }^{75}$ More recently, the United States government stepped into the debate over the proper standard for high definition television (HDTV), selecting a standard which unified U.S. development work but was at odds with other standards adopted in Japan and Europe. ${ }^{76}$ And government agencies such as the Advanced Research Projects Agency and the National Science Foundation have an historical role in the development of the Internet, including the creation of Internet interconnection protocols. Indeed, private Internet standard-setting groups such as InterNIC and the IETF were once government-sponsored standards organizations? ${ }^{7}$

Nonetheless, there are several reasons why government control of the standard-setting process should not be encouraged. First, government agencies are generally composed of career public servants, not market participants. As a result, they often do not involve the most qualified individuals in the industry at the moment in the standard-setting process. This is an inherent danger of bureaucracy, particularly when it attempts to regulate such a fast-moving area of commerce as the Internet. Government standard-setting groups may be slow, and may not always have access to the best information. Thus, even with the best of intentions, a government standard-setting organization may simply pick what is objectively a poor standard. ${ }^{78}$ Second, government-set standards may prove durable even when they are

75 FCC Rules, Part 68. By contrast, the Eshoo amendment to the Telecommunications Deregulation Act of 1996 limits the role of the FCC in setting cable compatibility standards.

76 See Denise Caruso, Debate over advanced TV gives the F.C.C. a chance to be assertive, N.Y. Times, June 17, 1996, at C5;F.C.C. Proposes Standards for Digital TelevisionN.Y. Times, May 10, 1996, at C4.

77 Government may also play a standard-setting role as a market participant, since it is often one of the largest customers of a given product. In most instances this public procurement does not create the same problems as government-mandated standards, however.

78 This almost happened in the case of the United States HDTV standard. Only by an accident of timing did the government adopt a digital HDTV standard, rather than an analog standard which would have been immediately obsolete. See, e.g., Joseph Farrell \& Carl Shapiro, Standard Setting in High Definition Television, 8 Brookings Papers on Econ. Activity 1 (1992); Nicholas Negroponte, Being Digital 37-40 (1995). 
demonstrably ill-conceived. ${ }^{79}$ While the market eventually will replace an inefficient standard by "leapfrogging," 80 there is no guarantee that the government will do the same. ${ }^{81}$ And since in our economy the market is the chief determinant of what is in fact efficient, it is not even clear that the government will recognize an inefficient standard in practice. ${ }^{82}$ Finally, as has been amply noted in the literature on public choice, government agencies in a position to influence the outcomes of market competition are highly susceptible to "capture" by private entities with an interest in the outcome. ${ }^{83}$ Thus, there is no guarantee that a government standard-setting body will act in the public interest, even if it is possible for them to discern what in fact that interest is ${ }^{84}$

79 This arguably has happened in the HDTV context, where the standard (set five years ago) has not proven to be the best technology in the new computer-driven marketSee Caruso, supra note , at C5.

80 See supra notes _____ and accompanying text.

81 Libicki studied government efforts to support seven sets of standards, and concluded that the government's efforts were generally unsuccessful, in part because "government is ponderous; it gets under way slowly and once a course is set plods on, well after everyone else may have taken a different path." Martin C. Libicki, Standards: The Rough Road to the Common Bytein Kahin \& Abbate eds.,supra note __, at 35, 75.

82 Ilene Knable Gotts and Alan Rutenberg make a related point -- that a government-mandated compatibility standard may reduce the incentives for innovation in the design of interfaces. Gotts \& Rutenberg, supra note $\ldots$, at 320 .

83 See generally Gabriel Kolko, Railroads and Regulation (1965); Theodore Lowi, The End of Liberalism (1969); R. Fellmeth, The Interstate Commission Omission: The Public Interest and the ICC (1970). Alternatively, even a government that is not acting at the behest of any private group may also hold its standard hostage to extraneous policy concerns. The government's repeated, misguided efforts to force the use of key-escrow cryptography, for example, have resulted in its refusal to allow the industry to converge on an efficient international standard for encryption. On this issue, see, e.g., A. Michael Froomkin, The Metaphor is the Key: Cryptography, the Clipper Chip, and the Constitution, 143 U. Pa. L. Rev. 709 (1995); Brock N. Meeks, Still Sucks: Clipper III, Wired, Aug. 1996, at 37.

84 Cf. David McGowan and Mark A. Lemley, Antitrust Immunity: State Action and Federalism, Petitioning and the First Amendment, 17 Harv. J.L. \& Pub. Pol'y 293, 315-22 (1994) (making an analogous argument with respect to government restrictions on trade). Once again, the argument can be made that the HDTV standard illustrates this problem. Even the current head of the F.C.C., which set the standard, appears to view it as "a creation of the broadcasting industry" designed to promote their interests. Caruso, supra note _, at C5. 
A final, perhaps more palatable approach to achieving interoperable standards is the adoption of a single standard by a private industry organization. ${ }^{85}$ If the members of such a private standard-setting group collectively have a significant market share, their adoption of a standard may produce the "tipping" effect described above, bringing the rest of the industry into line. ${ }^{86}$ Private standard-setting organizations are more efficient than government organizations in several respects. Because they are more market-oriented, they are less likely than their government counterparts to settle on an inefficient standard. If they do choose an inefficient standard, it may be less entrenched than an equivalent government standard, since private standards are potentially subject to "leapfrogging." Significantly, private group standard-setting may also be more efficient than de facto standardization, since having multiple companies participating in a standard means that those companies can compete to offer products incorporating the standard after it is selected, thus expanding output and lowering prices? 7

85 Such private organizations are relatively common in a variety of industries. For an historical review of standard setting in the United States, see L. Garcia, Standard Setting in the United States: Public and Private Sector Roles, IEEE Micro, Dec. 1993, at 28-35.

Significantly, Professor Farrell concludes for a variety of reasons that strong intellectual property protection is likely to hamper formal private standard-setting. Farrell, supra note __, at 44-45; accord Mark Shurmer \& Gary Lea, Telecommunications Standardization and Intellectual Property Rights: A Fundamental Dilemma?, in Kahin \& Abbate eds., supra note _, at 378, 384-89; E. Robert Yoches \& Kenneth M. Frankel, Legal Implications of Standards in the Computer and Software Industries, in Intellectual Property Antitrust (P.L.I. 1995). Thus, there may be a relationship between this option and the first one described above.

86 Of course, not all standard-setting groups have such market control. As Libicki observes, many of the most successful group standards started small and grew to become dominant. Libickiıpra note __, at 75 . See also Jim Isaak, Information Infrastructure Meta-Architecture and Cross-Industry Standardization, in Kahin \& Abbate eds., supra note _, at 100, 101 (group or open standards "must also reach the status of being 'de facto' to be sufficient.").

87 See David J. Teece, When is Virtual Virtuous? Organizing for Innovation, Harv. Bus. Rev., Jan.-Feb. 1996, at 69 (offering the IBM PC standard as an example of an open standard that resulted in significant intrastandard competition). 
To be sure, private group standard-setting does have problems. Private groups are not immune from capture, particularly where the standard to be set is exclusive rather than inclusive of competition. ${ }^{88}$ Agreement on private standards can be a time-consuming process, delaying innovation based on the standard while it is still being set. ${ }^{89}$ Private groups may also be a front for a cartel. Further, even an efficient open standard may become problematic over time. While an open standard allows an industry to evolve to improved technology as innovation progresses, that evolution may result in a group standard that becomes more cumbersome over time, as successive refinements are added to it. For example, it is probable that Microsoft's Windows operating system is more cumbersome than it would be if Microsoft did not have to ensure that it was compatible with early versions of its older DOS operating system. Over time, group standards may bog down in accumulated problems resulting from the need for backwards and horizontal compatibility. Nonetheless, if the choice is between a standard that evolves (as group standards generally do) and one that stagnates (as both government and private de facto standards are likely to do), most consumers would choose the dynamic standard, at least in an innovation-driven market like computer or Internet software. .90

Open standards present certain antitrust problems, however, which I discuss in the next section.

88 A clear example of an attempt to capture a private standard-setting organization is chronicled in Allied Tube \& Conduit Corp. v. Indian Head, Inc., 486 U.S. 492 (1988). In that case, Indian Head sought permission from the National Fire Protection Association to market polyvinyl electrical conduit. This required the NFPA to alter the National Electrical Code it had previously written, which allowed only steel conduit. Allied Tube, the nation's largest maker of steel conduit, packed the NFPA meeting and voted down the proposal. Id. at 49697. This case is considered in more detailinfra notes and accompanying text.

89 On this problem, and some ways to avoid it, see Joseph Farrell, Choosing the Rules for Formal Standardization(working paper April 1993).

90 See Shane Greenstein, Markets, Standards, and the Information Infrastructure, IEEE Micro, Dec. 1993, at 36 (arguing that on balance the benefits of private standard-setting outweigh the costs). 


\section{Antitrust and Standards}

Antitrust law protects competition and the competitive process, by preventing certain types of conduct that threaten a free market. For example, antitrust prohibits competitors from agreeing on the price they will charge. ${ }^{91}$ It prohibits certain "predatory" practices designed to exclude competitors from the market, and it places certain limits on the behavior of firms with market power. ${ }^{92}$ While there is some disagreement as to the original or proper goals of antitrust law, the dominant approach to antitrust law today is the "economic" or "social welfare" model. ${ }^{93}$ This approach takes the purpose of the antitrust laws to be promoting aggregate social welfare by ensuring that markets work efficiently and (to the extent possible) without government interference.

The antitrust laws regulate business conduct in three basic ways. First, section 7 of the Clayton Act prohibits mergers and asset acquisitions where the effect of the acquisition may

9115 U.S.C. $\S 1$.

9215 U.S.C. $\S 2$.

93 In the last 40 years, a revolution has taken place in economic thought about antitrust. Led by the Chicago School, which emphasized allocative efficiency as the sole goal of antitrust law, see Robert H. Bork, The Antitrust Paradox: A Policy at War With Itself (1978); Richard A. Posner, Antitrust Law: An Economic Perspective (1976), this revolution has brought economic thinking to the forefront of virtually all antitrust analysis, whether or not the analyst subscribes to the particular tenets of the Chicago School. See, e.g., Symposium on Post-Chicago Law and Economics, 65 Chi.-Kent L. Rev. 3 (1989). The basic model is economic efficiency, though whose welfare should be considered and how remains a point of debate.

Other models of antitrust include the populist view that big is intrinsically bad -- for example, because it concentrates wealth, because it reduces product diversity, or because it concentrates political power. See, e.g., Walter Adams, The Bigness Complex: Industry, Labor and Government in the American Economy (1986). A related view treats the antitrust laws as essentially an unfair competition statute designed to protect small businesses from the ravages of competition, even at the expense of higher prices.

The social welfare model is subject to economic criticism for ignoring second- and third-order misallocative effects by focusing entirely on the market at issue. See, e.g., Richard Markovits, A Constructive Critique of the Traditional Definition and Use of the Concept of "The Effect of a Choice on Allocative (Economic) Efficiency": Why the Kaldor-Hicks Test, the Coast Theorem, and Virtually All Law-andEconomics Welfare Arguments are Wrong1993 U. Ill. L. Rev. 485. 
be substantially to lessen competition in a relevant market. ${ }^{94}$ Second, section 2 of the Sherman Act prohibits monopolization, judicially defined as acquiring or maintaining market power through anticompetitive conduct, as well as attempts to monopolize. ${ }^{95}$ Third, section 1 of the Sherman Act prohibits agreements, usually between competitors, which unreasonably restrain trade. ${ }^{96}$ The Clayton Act's prohibition on mergers does not concern us here, but both sections of the Sherman Act are important in understanding the antitrust rules likely to be applied in the Internet software industry.

\section{A. Monopolization by Standard-Stters}

Section 2 of the Sherman Act prohibits "monopolization." Significantly, courts distinguish between monopoly itself, which is perfectly legal, and monopolization, which is not. ${ }^{97}$ In the words of the most influential court case on the subject, "[i]t does not follow because [a defendant] had such a monopoly, that it 'monopolized' the ingot market: it may not have achieved monopoly; monopoly may have been thrust upon it."98 Evidently, something more than market power is required for antitrust condemnation under section 2 . That "something more" is the acquisition or maintenance of monopoly through anticompetitive conduct, as distinguished from growth or development as a consequence of a superior product, business acumen, or historic accident. ${ }^{99}$ "Anticompetitive conduct" as defined by the

9415 U.S.C. $\S 18$.

9515 U.S.C. $\S 2$.

9615 U.S.C. $\S 1$. Both section 1 and section 2 of the Sherman Act are notoriously vague, and their contours have been defined almost entirely by court decisions. While section 1 of the Sherman Act by its literal terms prohibits all restraints of trade, the Supreme Court rapidly concluded that such a restriction was unworkable, and deemed the statute to cover only unreasonable restraints of trade. See, e.g., Standard Oil Co. v. United States, 221 U.S. 1 (1911).

97 See Berkey Photo, Inc. v. Eastman Kodak Co., 603 F.2d 263 (2d Cir. 1979); United States v. Alcoa, 148 F.2d 416 (2d Cir. 1945).

$98 I d$.

99 Id.; Spectrum Sports, Inc. v. McQuillen, 113 S. Ct. 457 (1993); United States v. Grinnell Corp., 384 U.S. 563 (1966). 
courts may be shown in a variety of ways, notably by proving that that alleged monopolist has engaged in some form of conduct that itself violates some other provision of the antitrust laws (tying, resale price maintenance, etc.) in an effort to monopolize. ${ }^{100}$ In addition, unilateral conduct that is legal under most circumstances may be considered anticompetitive conduct sufficient to prove monopolization when engaged in by a party with market power. ${ }^{101}$ Thus, under current law, monopolists face greater restrictions on their unilateral conduct under section 2 than do other competitors.

The peculiar economics of software (and particularly Internet software) markets present a real problem for section 2 analysis. The problem has three components. First, applying section 2 to a standardized software market with a single dominant firm arguably does not fit very well with existing precedent. The factors discussed in Part I above will tend to drive an unregulated software market to monopoly, at least where the standard adopted is proprietary. While in the ordinary case control of a market by a single firm may raise section 2 concerns, in this case the monopolist may have some legitimate claim that its monopoly has been "thrust upon it" and is therefore not illegal under the rule of United States v. Aluminum Co. of America (Alcoa).102 Courts have generally exculpated antitrust defendants whose major offense was possessing an inherent or "natural" monopoly. Thus, the owner of the only newspaper in a small town, ${ }^{103}$ the only football team in a medium-sized town, ${ }^{104}$ and even the

100 See generally Standard Oil Co. v. United States, 221 U.S. 1 (1911) (conduct which itself violates the antitrust laws meets the "anticompetitive conduct" requirement).

101 For example, in Aspen Skiing Co. v. Aspen Highlands Skiing Corp., 472 U.S. 585 (1985), the Supreme Court held that the defendant possessed market power in the market for ski facilities in the Aspen, Colorado area, and that it violated section 2 when it attempted to impose restrictive conditions on a "joint lift ticket" marketed with its sole rival in the area. The Court noted that while refusing to deal with a competitor is generally perfectly legal, see Olympia Equip. Leasing Co. v. Western Union Tel. Co., 797 F.2d 370 (7th Cir. 1986), a dominant firm that has a history of dealing with its competitor may be obliged to continue to do so. This result is somewhat puzzling.

102148 F.2d at 416; accord Grinnell, 384 U.S. at 563; American Tobacco Co. v. United States, 328 U.S. 781 (1946).

103 See, e.g., Union Leader Corp. v. Newspapers of New England, 284 F.2d 582 (1st Cir. 1960). 
owner of the only facility currently capable of making a certain product $^{105}$ have defeated antitrust claims against them on the grounds that their monopolies were "natural."

In most markets, this hands-off rule has been tempered by greater antitrust scrutiny of the natural monopolist's attempts to maintain its dominant position. Thus, even a regulated electric utility with a monopoly conferred in part by government franchise violated the antitrust laws when it denied access to power transmission to towns that wished to buy their power elsewhere. ${ }^{106}$ Antitrust also seeks to limit the ability of a natural monopolist to extend its monopoly into other competitive markets, by what is sometimes referred to as "monopoly leveraging." 107 But in a standardized market such as Internet software, once the tipping effect gives a particular company a monopoly, that monopoly is likely to be quite durable. While it will not hold a monopoly position forever, a company in such a position can keep its market power for sometime with a relative minimum of effort -- and without engaging in

104 See American Football League v. National Football League, 323 F.2d 124 (4th Cir. 1963).

105 See Ovitron Corp. v. General Motors, 295 F. Supp. 373 (S.D.N.Y. 1969). In that case, however, the court went on to hold that defendant Delco had gone beyond possession of a natural monopoly and had engaged in predatory pricing with the aim of maintaining and extending its monopoly power once potential competition arose. See infra note

106 Otter Tail Power Co. v. United States, 410 U.S. 366 (1973); see also Ovitron, 295 F. Supp. at 373 (predatory pricing by natural monopolist served to artificially maintain monopoly power, and therefore violated section 2).

107 This effort was behind the consent decree breaking up AT\&T in 1982. The government argued that AT\&T's vertical integration allowed it to unfairly use the advantages of its entrenched local telephone monopoly to dominate the competitive market for long-distance service. United States v. AT\&T, 552 F. Supp. 131 (D.D.C. 1982), aff'd sub nom. Maryland v. United States, 460 U.S. 1001 (1983).

There is considerable controversy attending the idea of "monopoly leveraging." Commentators have disagreed sharply over whether such leveraging is ever economically rational. Compare Bork, supra note _ and Posner, supra note __ (both concluding that leveraging only redistributes among two markets the profits a company could have made from one market) with Louis Kaplow, Extension of Monopoly Power Through Leverage, 85 Colum. L. Rev. 515 (1985) (given market imperfections, monopoly leveraging can increase profits) and with Richard Markovits, An Ideal Antitrust Law Regime, 64 Tex. L. Rev. 251 (1985). And at least one court has held that leveraging itself is not illegal, though it held open the possibility that the conduct described as leveraging could have anticompetitive effects which violated the antitrust laws in other ways. Alaska Airlines v. United Airlines, 948 F.2d 536 (9th Cir. 1991). 
anticompetitive conduct designed to maintain or extend market power. This is particularly true if, as Professor Teece suggests, large companies already in the market have an advantage in future standards competitions because consumers will expect them to prevail. ${ }^{108}$ As the law now stands, courts will not act against a firm that obtains monopoly power without acting anticompetitively. ${ }^{109}$ Antitrust scrutiny of such a company is likely to be limited to the fringes, policing certain minor aspects of a defendant's conduct rather than attacking the defendant's dominant position itself. This seems to have been the fate of the government's notorious action against Microsoft for actions in the operating systems markete

A second problem with applying section 2 to dominant firms in the software industry is one of remedy. Even were the courts to reverse the long-standing rule and conclude that durable monopoly can and should be attacked by antitrust regardless of how that monopoly was obtained, it is not at all obvious how to go about applying the antitrust laws to such a monopolist. Antitrust offers three basic remedies to private plaintiffs -- treble actual damages, attorneys' fees, and injunctive relief against anticompetitive conduct.111 Injunctive relief seems inappropriate here, where by hypothesis there is no anticompetitive conduct to enjoin. The only injunction one can imagine being relevant -- one imposing an affirmative duty on a

108 See David J. Teece, When is Virtual Virtuous? Organizing for Innovation, Harv. Bus. Rev. Jan.-Feb. 1996, at 65-68.

109 Arguably, there is nothing the courts should do about a company in this position. See infra notes _and accompanying text;see also Lopatka \& Page,supra note __, at 349.

110 See United States v. Microsoft, 159 F.R.D. 318 (D.D.C.), rev'd on other grounds, 56 F.3d 1448 (D.C. Cir. 1995). In that case, the Antitrust Division challenged certain anticompetitive but minor aspects of Microsoft's sales and design policies. The District Court initially rejected the government's proposed consent decree with Microsoft on the grounds that it did not address the real issues with Microsoft's monopoly, but that decision was reversed by the D.C. Circuit on appeal. Most commentators have viewed the government's consent decree as ineffective. See, e.g., Kenneth C. Baseman, Frederick R. Warren-Boulton, \& Glenn A. Woroch, Microsoft Plays Hardball: The Use of Exclusionary Pricing and Technical Incompatibility to Maintain Monopoly Power in Markets for Operating System Software40 Antitrust Bull.265 (1995).

111 Clayton Act, §§ 4, 16. 
monopolist to predisclose and license its standards -- has repeatedly been rejected by Congress and the courts. ${ }^{112}$ Treble damages and attorneys' fees are a powerful incentive to private plaintiffs. ${ }^{113}$ But what are a plaintiff's actual damages? If the plaintiff is a competitor upset that it did not get the dominant position now held by the defendant, the measure of its injury is simply the revenue it lost by not itself being able to charge consumers a supra-competitive price. It is hard to imagine a court accepting such a damage theory, even if we set aside the probably insuperable problem of proving antitrust injury. ${ }^{114}$ Consumers might fare better; they could claim that the dominant firm had used its market power to overcharge them and that the measure of their injury is the extent to which the price of the dominant firm's good exceeds its cost. But accepting such a claim is tantamount to declaring ongoing judicial price regulation of the entire industry, something the antitrust laws have historically been loath to do -- and with good reason!15

112 See, e.g., Berkey Photo, Inc. v. Eastman Kodak Co., 603 F.2d 263 (2d Cir. 1979) (monopolist in camera market under no obligation to predisclose interface specifications of its new cameras to film makers, even though the result was to give monopolist temporary control over film market as well); 35 U.S.C. § 271(d)(4) (patentee has the right not to license its patent); United States Department of Justice and Federal Trade Commission, Antitrust Guidelines for the Licensing of Intellectual Property § 2.2 (1995) (possession of market power does not impose an antitrust obligation to license intellectual property).

113 Indeed, in the view of some commentators, the incentive to bring suit is too powerful. See, e.g., Thomas M. Jorde \& David J. Teece, Innovation, Cooperation and Antitrust: Balancing Cooperation and Competition, 4 High Tech. L.J. 1 (1989) (suggesting plaintiffs be limited to actual damages for certain types of antitrust violations).

114 Antitrust injury is a standing doctrine which requires antitrust plaintiffs to show that their losses reflect "injury of the sort which the antitrust laws were intended to prevent, and which flows from that which makes the conduct unlawful." Cargill, Inc. v. Monfort of Colorado, 479 U.S. 104 (1986); Brunswick Corp. v. Pueblo Bowl-O-Mat, Inc., 429 U.S. 477 (1977). Unless a court were to interpret the antitrust laws as intending to put the plaintiff rather than the defendant in a dominant position, a showing of antitrust injury in this situation is extremely unlikely. $C f$. Brunswick Corp. v. Riegel Textile, 752 F.2d 261 (7th Cir. 1984) (antitrust claim not viable where "Brunswick is asking, as a main part of the remedy, for an order transferring ownership of the patent from Riegel to itself. . . . There is nothing discreditable in this ambition but we do not see how consumers can benefit from its achievement.").

115 See supra notes ____ and accompanying text (discussing problems with government regulation of industry); see also Pierce, supra note 
Government regulators have an additional remedy in their armory -- they can seek structural relief against a defendant. ${ }^{116}$ Such relief might include an order divesting certain assets, the division of the company into separate operating groups, or even a flat prohibition against a company participating in a given market (say, an order barring Microsoft from competing in the market for applications programs). ${ }^{117}$ Yet even this drastic remedy seems futile in the face of the relentless economics of standardization. ${ }^{118}$ Suppose that antitrust regulators obtain structural relief against the dominant software provider in a market -- that they break it up into several pieces, or even bar the dominant player from the market entirely. What then? The analysis undertaken in Part II suggests that the firms that remain in the industry (and new entrants attracted by the potential to set the next-generation standard) will compete for a time, but that such competition will end with most of the participants driven out of business and the market settling on a new standard (offered by a new dominant company). Perhaps the antitrust process will begin again at that point, ${ }^{119}$ but it is hard to see that anything has really been accomplished, particularly given that both interim standards competition itself and enforcement of the antitrust laws involve significant social cošts.

There are two other possible remedial benefits to section 2 enforcement. First, it may be that the existence or threat of section 2 actions will be sufficient to deter anticompetitive conduct by standard-setters. However, it is not at all clear why section 2 enforcement efforts

\footnotetext{
116 Sherman Act $\S 4,15$ U.S.C. § 4; Clayton Act, $\S ~ 15,16$.

117 For example, the consent decree in United States v. AT\&T, discussed supra note __, involved all three types of relief.

118 See Lopatka \& Page,supra note __, at 349.

119 Cf. James J. Anton \& Dennis A. Yao, Standard-Setting Consortia, Antitrust, and High-Technology Industries, 64 Antitrust L.J. 247, 263 (1995) (remedies in complex standard-setting cases might involve ongoing "regulatory"-style interventions in the market).

120 See infra notes ___ a and accompanying text (identifying some such costs). See also Alaska Airlines v. United Airlines, 948 F.2d 536, 547-48 (structural relief not appropriate in such cases).
} 
directed at durable monopolies obtained through normal competitive means would be effective in preventing anticompetitive conduct. It seems at least as likely that such actions would deter reasonable, pro-competitive conduct.

Second, obtaining structural relief against the owners of standards will temporarily (though not permanently) solve the problem of the durable monopoly, by replacing it with a new standards competition. Whether or not this is a good thing depends on whether creating such a new standards competition is more efficient than remaining in a durable monopoly. Certainly such antitrust enforcement would temporarily reduce price-cost ratios, though it would have to be applied regularly. If timed properly, such relief could also benefit newlydeveloped, technologically superior products, by allowing them to compete immediately in a new standards competition. Structural relief would increase wasteful competition to set the new standard, however, since standards competitions would occur more frequently. ${ }^{121}$ Further, it is not clear that such antitrust-induced standards competitions would produce an efficient product choice, since the fear of future antitrust action might deter investment in new standard-setting. Whether such relief is worth the significant costs it would require is doubtful.

There is a final, more conceptual problem with applying section 2 to dominant firms in markets characterized by standardization. Historical quibbles notwithstanding, ${ }^{122}$ antitrust law today is fundamentally about enhancing competition. The classic statement of this rule is

121 See Daniel J. Gifford, Microsoft Corporation, the Justice Department, and Antitrust Theory, 25 Sw. U.L. Rev. 621, 638-39 (1996).

122 On the historical meaning of the Sherman Act, see, e.g., Adams, supra note __; Victor H. Kramer, The Supreme Court and Tying Arrangements: Antitrust as History, 69 Minn. L. Rev. 1013 (1985); F.M. Scherer, Efficiency, Fairness, and the Early Contributions of Economists to the Antitrust Debate, 29 Washburn L.J. 243 (1990). 
that the Sherman Act protects competition, not competitors. ${ }^{123}$ At least in the long run, the one thing section 2 of the Sherman Act cannot do in an industry such as this is enhance competition. Monopolists who acquire their power through the work of market forces rather than anticompetitive conduct will continue to do so as long as the market forces push in that direction. If the end result of antitrust action is a market which is dominated by a different company, but which is otherwise no more competitive than it was before the courts intervened, it is reasonable to question the point of the enterprise in the first place.

For these reasons, I think that if antitrust is viewed as a weapon to be used against entrenched monopolies relying on a product standard, it is doomed to failure. ${ }^{125}$ It does not follow from this, however, that section 2 should play no role whatever in Internet software markets. Standards do not last forever; they are periodically replaced by newer and presumably better standards. This is especially true in the context of the Internet, where the relevant standards competition sometimes seems to change on a monthly basis. As discussed

123 Brown Shoe Corp. v. United States, 370 U.S. 294 (1962). Ironically, the Court made this statement only to disavow it, indicating that it was interested primarily in protecting small independent businesses, allegedly as a vehicle for promoting competition. Nonetheless, it is the statement and not the Court's holding that has survived to the present day. See, e.g., Brooke Group v. Brown \& Williamson Tobacco Co., 509 U.S. 209 (1993) (applying theBrown Shoelanguage to restrict predatory pricing claims); Dratler,supra note __, at 682.

124 Cf. Brunswick Corp. v. Riegel Textile, 752 F.2d 261 (7th Cir. 1984). In Brunswick, Judge Posner treated the partially analogous case of a patent allegedly obtained by fraud and used to dominate a market. He concluded that the antitrust laws were not concerned with such fraud if the only effect was to give the patent to the wrong party, since "[t]he power over price that patent rights confer is lawful, and is no greater than it otherwise would be just because the person exercising the rights is not the one entitled by law to do so." Id. at

As noted above, it is not clear that Judge Posner is right. In certain circumstances, who owns patent rights (or, more relevant for our purposes, which product becomes a market standard) may make a good deal of difference in terms of social welfare. See supra note _. Nonetheless, the general point remains that attacking a monopoly cannot be justified on the grounds that that monopoly is bad if the outcome of the attack is a new monopoly which is not any better.

125 Of course, Schumpeterians and others who oppose any application of antitrust law to innovative industries because they do not believe in competition in such industries will not find this "failure" particularly troubling. See Ramsey Hanna, Note, Misusing Antitrust: The Search for Functional Copyright Misuse Standards, 46 Stan. L. Rev.401, 424-25 (1994). 
above, the period during which a new standard is set is frequently one of vigorous competition between potential standards. While such competition is in some senses inefficient -- parties may engage in wasteful rent-seeking ${ }^{126}$ in order to capture the dominant position, and consumers of unsuccessful standards may be stranded ${ }^{127}$-- it can also have a valuable marketdisciplining effect. At least in theory, competition to set standards should ensure that the "best" standard available at the time is the one that is selected?

Because de facto standard-setting is a high-stakes game -- the winner gets a durable monopoly for several years, and the losers get nothing -- participants in this competition may be expected to try to tip the balance in their favor. ${ }^{129}$ Many of these efforts will fall under the category of vigorous competition, something the antitrust laws seek to promote. For example, companies may compete to offer their product earlier, with more and better features, or at a lower price, in an effort to convince a critical mass of consumers to adopt it. But companies may also engage in potentially anticompetitive actions in an effort to become the market leader. ${ }^{130}$ Because the value of being a leader in a standardized market is sufficiently high, for example, this may be a case where such normally problematic antitrust theories as predatory pricing and monopoly leveraging actually make economic sense.

126 "Rent-seeking" refers to the tendency of market participants to expend resources in an effort to capture supracompetitive profits. See generally Posner, supra note

127 See supra notes _____ and accompanying text.

128 The "best" standard is somewhat tautologically defined here as the standard most preferred by consumers. Consumer preferences are complex things, and it may not be the case that the technically superior product will win the standards competition. See Dratler, supra note _, at 718. Factors such as price, widespread availability, and ease of use will also influence consumer decisions.

129 For discussion of the stakes in the current battle over Web browser standards, see Even Ramstad, Browser Battle Has High Stakes, Austin Am.-Statesman, Mar. 18, 1996, at D8. According to the article, Microsoft chair Bill Gates "wakes up every morning thinking about browser market share."

130 See Bar et al., supra note _, at 243 ("This possibility of influencing the allocation of long-term returns makes de facto standards competitions such fertile ground for corporate strategy."). 
Predatory pricing (pricing a product below marginal cost in an effort to gain market share) is alleged with much greater frequency than it actually occurs, a fact which has inclined courts and commentators against it. ${ }^{131}$ The normal problem with predatory pricing claims is that a firm will not price below costs unless it expects to be able to "recoup" its losses with supracompetitive pricing later. ${ }^{132}$ In a market with low barriers to entry, this strategy is unlikely to work, since once the predator raises its price, new entrants will compete and drive the prices back down. To the extent that standardization effects create a significant barrier to entry in software markets once a market standard has been established, they may make recoupment (and therefore predation) more likely. ${ }^{133}$ Certainly, the conventional explanation why both of the main competitors in the Web browser market have offered their products to the public for free is in order to capture browser market share.4

131 In Matsushita Elec. Ind. Co. v. Zenith Radio Corp., 475 U.S. 574, 589 (1986), the Supreme Court opined that "predatory pricing schemes are rarely tried, and even more rarely successful." Accord Frank Easterbrook, Predatory Strategies and Counterstrategies, 48 U. Chi. L. Rev. 263, 268 (1981); Fisher, Matsushita: Myth v. Analysis in the Economics of Predation, 64 Chi.-Kent L. Rev. 969, 970 (1988); Liebeler, Whither Predatory Pricing? From Areeda and Turner to Matsushita, 61 Notre Dame L. Rev. 1052 (1986); McGee, Predatory Pricing Revisited, 23 J.L. \& Econ.289, 295-97 (1980)

132 See Brooke Group v. Brown \& Williamson Tobacco, 509 U.S. 209 (1993) (requiring proof that predator will not only acquire market power, but will be able to raise prices sufficiently to recover the losses its suffered during the period it priced below cost). In the Court's words, "Recoupment is the ultimate object of an unlawful predatory pricing scheme; it is the means by which a predator profits from predation. Without it, predatory pricing produces lower aggregate prices in the market, and consumer welfare is enhanced."

133 See Farrell, supra note _, at 43 (predatory pricing strategies are common in marketplaces characterized by standards competition between proprietary technologies).

134 See supra note _ (discussing the browser market share battle); Peter H. Lewis, Netscape Knows Fame and Aspires to Fortune, N.Y. Times, March 1, 1995, at D1 (Netscape giving away certain versions of its browser software). More recently, Netscape has begun charging corporate users of its product; Microsoft still does not. See Froomkin, supra note _, at 29-30. While giving a product away for free certainly appears to be "pricing below marginal cost," generally accepted as a prerequisite for predatory pricing, standardization effects might make such giveaways economically rational (and legal), particularly if price discrimination is possible. In particular, since making its product the market standard redounds to the benefit of all adopters of the product, a company engaging in such pricing may in theory be able to make up the revenues it has lost by giving away a product by charging a higher price in another segment of the market (whose value and therefore willingness to pay has been increased by broad adoption of the standard). Such price discrimination is possible only to the extent that the company can prevent arbitrage, however, which seems unlikely in this industry. See 
However, rent-seeking during the competition period may counterbalance this effect to some extent. For example, if ten firms each know that victory in a standards battle will allow them to reap significant supracompetitive profits, each will have a similar incentive to predate. This "competitive predation" may drive up the costs each firm would have to incur to prevail, reduce the market penetration value of pricing below cost, and therefore make predation less desirable to the firm. ${ }^{135}$ The current market battle over Web browser standards may be an example of such competitive predation, with both parties giving away their key software in an effort to capture market share and, eventually, the standard.136 If, as Professor Farrell concludes, a standards competition between two proprietary technologies, both of which may be priced predatorily, should nonetheless tip the market towards the long-run superior technology, ${ }^{137}$ there is reason to be concerned about predation in this context only to the extent that it is asymmetric -- that is, only if for some reason one firm is much better situated to survive a predatory pricing battle. In cases of symmetric competitive predation, where both firms have sufficient resources to engage in the competition, it is hard to see how consumers will be harmed by the outcome of the competition.

Symmetric (or even slightly asymmetric) competitive predation presents another, more practical problem for antitrust enforcement -- the problem of knowing who to sue. Take the Microsoft-Netscape browser battle as an example. Which of these companies is the dangerous

generally Richard Markovits, An Ideal Antitrust Law Regime, 64 Tex. L. Rev. 251, 304-05 (1985) (cost of avoiding arbitrage makes price discrimination allocatively inefficient).

135 Besen and Farrell model such competitive predation in terms similar to the "dollar auction" familiar to economists. They conclude that firm expenditures to predate in standardized markets may fritter away most of the value of capturing the standard. Besen \& Farrellsupra note __, at 120 n.6.

136 See supra note _ (discussing browser competition). While it is possible to define below-cost pricing in such a way that giving your product away does not meet the test, see supra note _, by most definitions the conduct engaged in by both Microsoft and (for some products) Netscape constitutes below-cost pricing.

137 Farrell, supra note __, at 43. 
monopolist who must be stopped? The immediate answer from those schooled in the operating system market may be: Microsoft. But it is Netscape, not Microsoft, that has an $85 \%$ market share today, and it would seem odd to prosecute a fringe competitor in such a market. ${ }^{138}$ People interested in the industry can spend hours debating who will win this competition; perhaps that fact alone should incline antitrust enforcers against acting at all.

Alternatively, it is possible that giving away browsers is seen by both Microsoft and Netscape as an entry into a market which will eventually be composed of a suite of programs, for many of which the companies could charge. On this theory, the browser battle is really directed at the so-called "intranet" market -- internal corporate networks using Internetcompliant technology. ${ }^{139}$ Microsoft's recent market approach, for example, seems to involve embedding Internet applications deeply within its server operating systems, thus linking these two markets more tightly. ${ }^{140}$ Since Microsoft currently does rather better at maintaining market share for operating systems than it does for Web browsers, some might call this an effort to leverage its monopoly into a new markett ${ }^{1}$

Monopoly leveraging is in a position similar to predation. The whole idea of leveraging has been criticized by some commentators on the grounds that monopolists could obtain the same profits from their existing market as they could from the market they sought

138 See Dratler, supra note _ at 735 . Of course, the dynamics in this market are somewhat more complicated than suggested in the text. In particular, the browser market may be valuable to companies like Microsoft not just for itself, but for the control it confers over other, more lucrative markets (such as the next generation computer operating system market). Thus, it may be that in considering market power, we need to look at more than just browsers alone. See infra notes ___ and accompanying text (discussing the possibility of leveraging from the browser market).

139 See John Markoff,Microsoft Plans New Bid for Internet ContralN.Y. Times, June 13, 1996, at C4.

140 See Jay Dratler Jr., Microsoft as an Antitrust Target: IBM in Software?, 25 Sw. U.L. Rev. 671, 672 (1996); Peter H. Lewis, New World Brought to You by . ., N.Y. Times, July 30, 1996, at B6; John Markoff, Microsoft and the Web: Making Critical Mass PayN.Y. Times, July 29, 1996, at C1-C2.

141 Indeed, a Microsoft spokesperson seemed to acknowledge this goal in a recent statement. See John Markoff, Tomorrow, the World Wide Web,'N.Y. Times, July 16, 1996, at C1, C5. 
to enter. ${ }^{142}$ However, leveraging from a traditional to a standardized market may make economic sense, because obtaining control at the proper time can result in a durable monopoly, something that may not be possible in other markets with lower barriers to entry. ${ }^{143}$ An example of such leveraging may be at work in the Web browser market, where underdog competitor Microsoft managed to convince the largest private online service provider, America Online, to feature Microsoft's Internet Explorer browser as its primary Web software. In return, Microsoft offered AOL preferred placement on all future versions of the Windows 95 desktop. ${ }^{144}$ Alternatively, Microsoft might be portrayed as seeking to capture the Web browser market in order to shore up its control of the personal computer operating systems market. This latter theory is also a claim of leveraging, albeit a more subtle one: on this view, Microsoft wants to capture the browser market to ensure that its operating system monopoly is not outflanked by a new generation of computer operating systems integrated into Web browsers ${ }^{145}$

142 See Bork, supra note __; Posner, supra note _. These scholars argue that a monopolist has no incentive to leverage her monopoly, since any profits she can coerce out of the new market, she could also take from the existing market.

143 Cf. Louis Kaplow, Extension of Monopoly Power Through Leverage, 85 Colum. L. Rev. 515 (1985). Kaplow offers persuasive reasons why monopoly leveraging may be anticompetitive in markets characterized by imperfections, or which do not possess the simple one-for-one vertical substitutability assumed in the basic Chicago model. See also Roger D. Blair \& Amanda K. Esquibel, Some Remarks on Monopoly Leveraging, 40 Antitrust Bull. 371 (1995) (leveraging which leads to significant market share, but not to monopoly, may still impose welfare losses).

144 See Peter H. Lewis,Microsoft Gets a Big Boost on Interneł N.Y. Times, Mar. 13, 1996, at C1.

There have also been allegations that Microsoft has attempted to leverage its market power in software operating systems directly into the Internet access market, by making it difficult for consumers to use software in a Windows environment to access online services other than Microsoft's Network. The Justice Department investigated such complaints in 1995. See, e.g., Michele Matassa Flores, U.S. Investigates Microsoft's Handle on Internet, Austin Am.-Statesman, Dec. 5, 1995, at D1; James Gleick, Making Microsoft Safe for Capitalism, N.Y. Times Mag., Nov. 5, 1995, at 50. More recently, however, the failure of Microsoft Network to make significant inroads against its competitors (and the fierce competitiveness of the related market for Internet service providers) has taken much of the steam out of these complaints.

145 Some of Microsoft's recent actions, notably adapting its products to "embrace and extend" existing Internet standards and linking its OLE operating system technology to its browser, are consistent with this 
During the period of competition to set a standard, antitrust can in theory serve a valuable role as market referee. By ensuring that the standards competition is resolved on the merits of the competing products, rather than on the basis of power leveraged from other contexts, this form of antitrust scrutiny would promote social welfare at least to some extent. This "refereeing" may take the form of actions to enjoin particular acts of leveraging in circumstances where it is anticompetitive. Alternatively, it could take the much more drastic form of structural relief, blocking leveraging by removing the defendant from one of the markets entirely. ${ }^{146}$ The market may still be locked into a new standard, but at least it will be the best possible standard. ${ }^{47}$

However, even this more limited use of section 2 faces practical problems. Like merger analysis under section 7 of the Clayton Act, it is extremely time-sensitive. The time to prevent anticompetitive conduct designed to influence a standards competition is when the conduct occurs, not after the standard has already been set. In the fast-paced world of the Internet, where the definitions of the market seem to change almost monthly, ${ }^{148}$ well-timed action is especially important. Unfortunately, antitrust cases are notoriously slow, and the more complex the industry, the slower they seem to be. Microsoft was investigated for years before a complaint was even filed; ${ }^{149}$ the government's prosecution of IBM went on for 13

theory. See John Markoff, Microsoft Plans New Bid for Internet Control, N.Y. Times, June 13, 1996, at C4. Evidence that this is really what is going on might also be seen in Sun Microsystems' recent decision to make Java the core of a new computer operating system. See Ed Anuff, Windows Meet Java, Wired, Aug. 1996, at 38.

146 Such a remedy was used to stop leveraging in the United States v. AT\&T case, see United States v. AT\&T, 552 F. Supp. 131 (D.D.C. 1982), aff'd sub nom. Maryland v. United States, 460 U.S. 1001 (1983), and has occasionally been proposed as a remedy for Microsoft's alleged leveraging from the computer operating systems market to the applications program market.

$147 C f$. Union Leader Corp. v. Newspapers of New England, 284 F.2d 582 (1st Cir. 1960) for an example of a court judging such a competition.

148 See Peter H. Lewis, New World Brought to You by . ., N.Y. Times, July 30, 1996, at B6.

149 See Gleick, supra note __; Gotts \& Fogt,supra note __, at 18. 
years before being dismissed during trial. ${ }^{150}$ And section 2 enforcers lack even the procedural advantages enjoyed by their counterparts in merger enforcement: pre-merger notification and approval rules ${ }^{151}$ and a relatively clear set of guidelines to apply. ${ }^{152}$ As a result, antitrust in the computer industry frequently seems to be looking backward rather than forward, focusing on the last generation's monopolist rather than the next generation's. Unless this problem can be overcome -- and it is hard to see how to do $\mathrm{so}^{153}$-- the practical utility of section 2 in this industry may be limited even during the standard-setting period.

\section{B. Antitrust Treatment of Standard-Setting Organizations}

Not all privately-set standards result from the success of a single firm in market competition. As discussed in section II above, an alternate means of standard-setting is for potential competitiors to get together, perhaps at a trade association meeting or in a group convened specifically for this purpose, and agree on a single technical standard that they each will use. Group standard setting has some obvious advantages over de facto standard setting. Notably, the end result of a group standard-setting process is that a number of different companies can compete to sell products implementing the standard, thereby offering the hope that at least some competition will occur in the market. Group standard setting may also

150 See Elanor Fox \& Larry Sullivan, Cases and Materials on Antitrust 202-203 (1988) (describing history of the litigation).

151 Clayton Act, § 7A.

152 United States Department of Justice Merger Guidelines (1992).

153 The time spent in investigating and prosecuting a monopolization claim involves learning about the industry and the specific acts at issue, often from disgruntled competitors or consumers; investigating the company and the industry, which generally involves issuing Civil Investigative Demands (CIDs) to obtain prelitigation discovery from the investigation target; evaluating the evidence and the case, and obtaining bureaucratic and political approval to proceed; preparing and filing the complaint and supporting evidence; preparing for and holding a court hearing; and, in some cases, investigating compliance and engaging in further enforcement. Even if some of these procedures could be compressed or done concurrently, it is hard to imagine that the process can be accelerated dramatically. 
promote competition in the development of improvements to the standard, since each of the competitors may seek advantage over the others by improving the design in ways compatible with the basic interface specification $35^{4}$

Unfortunately, section 1 of the Sherman Act, which prohibits conspiracies in restraint of trade, poses a potentially significant barrier to standard-setting organizations. Private group standard setting necessarily involves getting competitors together over a period of time to discuss the technical details of their current products and their plans for the future. Section 1 historically has been quite hostile to this form of information exchange among competitors, viewing it (with some justification) as a likely means for facilitating a cartel. ${ }^{155}$ A series of early cases held that the exchange of price information is highly suspect, and may even be illegal per se under section $1 .{ }^{156}$ Even the exchange of non-price information, such as would have to occur in a standard-setting organization, has been held illegal in certain cases where it may have anticompetitive effects. ${ }^{157}$ And one court considering standard-setting bodies in the computer software industry has held that any evidence suggesting that the purpose or effect of

154 As noted above, there are also potential problems with group standard setting, including the danger that one company will capture the standard-setting process and the problem of discouraging leapfrogging improvements. See supra notes _____ and accompanying text.

155 Public standard setting is not subject to the same form of scrutiny because it falls within the antitrust immunity afforded state action and efforts to petition the state. See generally David McGowan \& Mark A. Lemley, Antitrust Immunity: State Action and Federalism, Petitioning and the First Amendment, 17 Harv. J.L. \& Pub. Pol'y.293 (1994).

156 See, e.g., American Column \& Lumber Co. v. United States, 257 U.S. 377 (1921); United States v. Container Corp., 393 U.S. 333 (1969); Standard Sanitary Mfg. Co. v. United States, 226 U.S. 20 (1912); National Macaroni Mfgrs. Ass'n v. FTC, 345 F.2d 421 (7th Cir. 1965); Milk \& Ice Cream Can Inst. v. FTC, 152 F.2d 478 (7th Cir. 1946).

157 See Eastern States Retail Lumber Dealers Ass'n v. United States, 234 U.S. 600 (1914) (exchange of information supporting a boycott of competitors at trade association meeting violated section 1); $c f$. Allied Tube \& Conduit Corp. v. Indian Head, Inc., 486 U.S. 492, 500 (1988) (describing standard-setting as an implicit form of product restriction); National Society of Professional Engineers v. United States, 435 U.S. 679 (1978) (trade association rules cannot be justified under rule of reason except on grounds that they are procompetitive). 
such a group is to give its members an advantage over competitors creates a genuine issue of fact for trial under the rule of reason, despite serious questions about whether the standard had or was likely to acquire any market power. ${ }^{158}$ The result has been a reluctance among at least some groups to engage in formal standard-setting for fear of antitrust liabilifey.

Automatic condemnation of standard-setting organizations under section 1 is unwarranted. ${ }^{160}$ While exchanges of information between competitors do pose a risk of cartel facilitation in certain circumstances, particularly where the industry is already concentrated, those risks are significantly ameliorated in the Internet software context for three reasons. First, the exchange of information can provide procompetitive benefits the market would not otherwise provide, by allowing a number of different firms to produce and market competing products compatible with a single standard. ${ }^{161}$ To the extent that this makes the market for the standard more competitive, it will reduce the price of the standard and therefore facilitate

158 Adamaxx Corp. v. Open Software Found., 888 F. Supp. 274, 281, 284 (D. Mass. 1995). The court held that the OSF Unix standard presented a genuine issue of material fact with respect to the issue of monopsony power, despite the fact that the standard enjoyed virtually no sales in the UNIX market $d$. at 284 .

159 See S. Besen \& C. Johnson, Compatibility Standards, Competition and Innovation in the Broadcasting Industry(1986) (discussing standards for AM radio broadcast).

160 For conforming views, see Jack E. Brown, Technology Joint Ventures to Set Standards or Define Interfaces, 61 Antitrust L.J. 921 (1993); Howe \& Badger, The Antitrust Challenge to Non-Profit Certification Organizations: Conflicts of Interest and a Practical Rule of Reason Approach to Certification Programs as Industry-Wide Builders of Competition and Efficiency, 60 Wash. U.L.Q. 357 (1982) (endorsing fact-specific rule of reason approach); Thomas A. Priaino, Jr., The Antitrust Analysis of Network Joint Ventures, 47 Hastings L.J. 5 (1995); David J. Teece, Information Sharing, Cooperation and Antitrust, 62 Antitrust L.J. 474 (1994). Some commentators have gone further, taking the position that cooperation between competitors should be encouraged in high-technology industries as a means of promoting innovation. See Jorde \& Teece, supra note __ (encouraging lenient antitrust treatment of joint ventures).

161 See supra notes ___-__ and accompanying text. 
its wider adoption. ${ }^{162}$ Indeed, in certain industries the need for standardization is so great that it is impossible to compete effectively without group standardization efforfs.

Second, the risk to competition posed by such an information exchange -- that the participating companies will band together to raise prices and restrict output -- is much less disturbing if the alternative to group standard-setting is a de facto monopoly, rather than robust competition. Finally, the setting of voluntary product standards does not carry with it the same danger of capture and exclusion that inheres in prohibitory standard-setting organizations (those with the power to bar a product from the market directly), of the type that were at issue in Allied Tube and similar cases. ${ }^{164}$ The Internet Engineering Task Force (IETF), which sets technical interface standards for the communications functions of the Internet, is an example of a group standard-setting organization which is clearly necessary and which historically has posed little or no danger to competition, since it traditionally has not adopted proprietary private standards. 65

There is some indication in the caselaw that courts interpreting section 1 will be flexible in their treatment of standard-setting organizations. ${ }^{166}$ In one early information-

162 See Farrell, supra note __, at 3.

163 For example, Annalee Saxenian describes the detailed efforts that went into standardization in the semiconductor industry in Silicon Valley. Annalee Saxenian, Regional Advantage: Culture and Competition in Silicon Valley and Route 12849 (1994). Saxenian attributes the success of Silicon Valley and the failure of Route 128 in significant part to the existence of such a culture of cooperation.

164 See Allied Tube \& Conduit Corp. v. Indian Head Inc., 486 U.S. 492 (1988); American Soc'y of Mech. Eng. v. Hydrolevel Corp., 456 U.S. 556 (1982); Radiant Burners v. People's Gas Light \& Coke Co., 364 U.S. 656 (1961).

165 There is a proposal pending in an IETF working group to revise this policy, allowing standards to be owned by private companies providing they offer licenses on "fair and reasonable terms." Mark Voorhees, Internet Task Force Wakes Up to Reality of Intellectual Property, InfoLaw Alert, Feb. 9 , 1996 (http://infolawalert.com/stories/020996a.html). For a general description of the workings of the IETF, see Froomkin, International Law, supra note __, at 16-22; Froomkin, Regulatory Arbitrage, supra note __, at 3; Paulina Borsook,How Anarchy Works 3.10 Wired 110 (Oct. 1995).

166 Section 1 analysis is in any event relying increasingly on a case-by-case, rule of reason approach, rather than the traditional rule that all horizontal restraints were illegal per se. See, e.g., Thomas M. Jorde \& Mark 
exchange case, Maple Flooring Mfgrs. Ass'n. v. United States, the Supreme Court held that a trade association that exchanged information in order to promote product standardization acted reasonably and therefore lawfully, even though the association distributed some general price data. ${ }^{167}$ The Court distinguished American Column \& Lumber, discussed above, ${ }^{168}$ on the ground that in that case much of the information exchanged could only be used for anticompetitive purposes, while in Maple Flooring there was a legitimate purpose for the exchange, and the association took some steps to prevent the disclosure of unnecessarily detailed information. ${ }^{169}$ Further, more recent cases such as Broadcast Music, Inc. v. Columbia Broadcasting System ${ }^{170}$ have allowed even joint price setting in circumstances in which the collaborative action was necessary to facilitate market exchange, and thus create opportunities for trade that would otherwise have been lost. ${ }^{171}$ This arguably bodes well for collective action by competitors in a standards-driven industry, since they can argue that the

A. Lemley, Summary Judgment in Antitrust Cases: Understanding Monsanto and Matsushita, 36 Antitrust Bull. 271 (1991) (citing cases); Piraino,supra note , at 8 .

167 Maple Flooring Mfgrs. Ass'n v. United States, 268 U.S. 563 (1925).

168 See supra note _..

169 Maple Flooring, 268 U.S. at 563. Accord Adamaxx, 888 F. Supp. at 282, 283 ("it is clear that the effects of market standardization on the computer industry are extraordinarily difficult to gauge. . . The sheer complexity of the industry cautions against a per se analysis here."); Clamp-All Corp. v. Cast Iron Soil Pipe Inst., 851 F.2d 478 (1st Cir. 1988).

170441 U.S. 1 (1979).

$171 \mathrm{Id}$. at _. Joint ventures with arguably procompetitive effects have also benefited from rule of reason scrutiny rather than per se condemnation. See, e.g., SCFC ILC v. Visa USA, 36 F.3d 958, 964 (10th Cir. 1994); Northrop Corp. v. McDonnell Douglas Corp., 705 F.2d 1030 (9th Cir. 1983); SCM Corp. v. Xerox Corp., 645 F.2d 1195 (2d Cir. 1981); see also 15 U.S.C. § 4301 et seq. (providing special treatment to research, development and production joint ventures registered with the Department of Justice). Standardsetting organizations overlap to some extent in structure and purpose with joint ventures, such that antitrust treatment of joint ventures might be relevant in evaluating standards groups as well. See Addamax Corp. v. Open Software Found., 888 F. Supp. 274, 280-81 (D. Mass. 1995) (treating standard-setting organization as a joint venture for antitrust purposes); Andrew Updegrove, Forming and Representing High Tech Consortia: Legal and Strategic Issues Comp. Law, Mar. 1994, at 8. 
alternative to joint standard-setting is likely to be monopoly. This more flexible treatment of standardization efforts must continue if group standardization is to be a viable alternative. In short, in this particular context, the best thing the antitrust laws can do to promote competition is not to interfere with industry cooperation? ${ }^{2}$

Again, however, it does not follow that antitrust has no role in this area. Two types of joint standard-setting activity in particular may raise antitrust concerns. First, some standardsetting organizations restrict access to the standard to members of the organization. In industry terms, the standards are "closed" rather than "open."173 This restriction may be problematic if the membership of the organization is only a subset of the full industry, since access to the standard will be critical to competition. Such a partially-closed group may be able to limit effective competition in the industry to competition between members of the group. ${ }^{174}$

Antitrust treats such claims of exclusion from private groups in one of two ways. First, closing the group might be viewed as a horizontal group boycott or concerted refusal to

172 But see James J. Anton \& Dennis A. Yao, Standard-Setting Consortia, Antitrust, and High-Technology Industries, 64 Antitrust L.J. 247, 248, 262-63 (1995) (arguing for antitrust review of the substantive merits of a group standard in some cases).

173 Bar et al. point to standards which are neither fully closed nor fully open, largely because some competitors have an information advantage over others. Bar et al., supra note _, at 240. See also William Lehr, Compatibility Standards and Interoperability: Lessons from the Internet, in Kahin \& Abbate eds., supra note _., at 121, 123 (most compatibility standards produce only partial interoperability).

One commentator distinguishes between nonpartisan "specification groups" such as the IETF, which "are primarily concerned with assuring the development of a usable, robust standard for the benefit of the industry generally," and "strategic consortia" formed by a subset of an industry to advance particular economic interests. Updegrove, supra note _. Interestingly, Updegrove concludes that the impartial groups are longer lasting and more successful. Id. at _ . Of course, making such a determination requires some sort of benchmark for distinguishing between a non-partisan group and a strategically-dominated one, a benchmark which is hard to find.

174 See Joseph Farrell \& Garth Saloner, Standardization, Compatibility, and Innovation, 16 Rand J. Econ. 70 (1985) (formal standard-setting risks manipulation by dominant firms in order to preserve dominance); Piraino, supra note _, at 9 (suggesting that network joint ventures should be required to open their membership on nondiscriminatory terms). 
deal with competitors. While the parameters of the antitrust prohibition against group boycotts are far from clear, ${ }^{175}$ the Supreme Court's decision in Northwest Wholesale is instructive. There, the plaintiff sued a wholesale purchasing cooperative that had denied it membership (and accompanying discounts on products purchased in bulk by the cooperative). The Court nominally applied a per se rule condemning the joint refusal to deal, but in fact engaged in a rule-of-reason type of inquiry, seeking to determine the importance of membership to effective competition and whether "the boycotting firms possessed a dominant position in the relevant market."176 The rule against group boycotts has also been applied (again under the rule of reason) to the New York Stock Exchange, a body which is at least in part a standard-setting organization..$^{77}$

Alternatively, antitrust might treat access to a standard-setting organization (or at least its interface standards) as an "essential facility." Under this doctrine, the owners of facilities that are essential to effective competition must make them available to competitors on nondiscriminatory terms. Thus, the railroads which collectively owned the only railroad switching yard in St. Louis at the height of the railroad era were required to give all railroads access to the yard on equal terms. ${ }^{178}$ Similarly, regulated local telephone monopolies must

\footnotetext{
175 See, e.g., Northwest Wholesale Stationers Inc. v. Pacific Stationery \& Printing, 472 U.S. 284, 294 (1985). For other statements of the confusion surrounding group boycott law, see Philip Areeda, Antitrust Analysis 381 (2d ed. 1974);Lawrence A. Sullivan, Handbook of the Law of Antitrust29-230 (1977).
}

176 Northwest Wholesale, 472 U.S. at 294. Cf. FTC v. Indiana Federation of Dentists, 476 U.S. 447 (1986) (applying a "quick look" rule of reason to an agreement by dentists to deny information to insurers). The Court in Indiana Federation held the agreement unlawful because the dentists failed to offer a procompetitive justification for their actions.

177 See Silver v. New York Stock Exchange, 373 U.S. 341 (1963) (refusing to invalidate NYSE restrictions on membership, in part because the Exchange was already subject to heavy SEC regulation).

178 United States v. Terminal Railroad Ass'n, 224 U.S. 383 (1912). 
interconnect all long distance carriers on substantially equal terms. ${ }^{179}$ A similar claim that membership in a standard-setting organization (or at least access to its work product) was essential to competition in a networked industry arguably would guarantee a "level playing field" for all competitors.

It is not clear which of these two legal theories would apply in the case of the Internet. The essential facilities doctrine has been roundly criticized as overbroad. Professor Areeda called it "an epithet in search of a limiting principle."180 And the vast majority of essential facilities claims are rejected by the courts, even in circumstances where control over a facility confers a substantial advantage upon a competitor. ${ }^{181}$ Further, a decision to apply the essential facilities doctrine to standardized industries would offer no way to distinguish group standards from individual standards, and therefore could dramatically expand the scope of antitrust intervention in the market. ${ }^{182}$ Group boycott claims, by contrast, do attempt to distinguish concerted action to boycott a competitor (which is subject to section 1 scrutiny)183

179 MCI v. AT\&T, 708 F.2d 1081 (7th Cir. 1982); see Mark C. Rosenblum, The Antitrust Rationale for the MFJ's Line-of-Business Restrictions and a Policy Proposal for Removing Them, 25 Sw. U.L. Rev. 605, 60811 (1996).

180 Philip Areeda, . See also McGowan, supra note _, at __ (arguing that essential facilities claims should be limited to natural monopoly situations). But see Farrell, supra note _, at 8-9 (arguing that essential facilities claims may be justified in the circumstances of networked markets).

181 See, e.g., City of Anaheim v. Southern California Edison Co., 955 F.2d 1373 (9th Cir. 1992) (access to electric power transmission lines not essential); Alaska Airlines v. United Airlines, 948 F.2d 536 (9th Cir. 1991) (access to airline computer reservation system not essential); Illinois ex rel Burris v. Panhandle Eastern Pipe Line Co., 935 F.2d 1469 (7th Cir. 1991) (natural gas pipeline facilities not essential, even though duplicating transportation system would have been infeasible); 3 Julian O. von Kalinowski, Antitrust Laws and Trade Regulation§ 19.05[3], at 19-124 (2d ed. 1995) (cataloguing essential facilities cases).

182 See supra notes _-_ and accompanying text (discussing limits on section 2 in the standardization context); but cf. Maureen A. O'Rourke, Drawing the Boundary Between Copyright and Contract: Copyright Preemption of Software License Terms, 45 Duke L.J. 479, 547 (1995) (arguing for application of essential facilities rule in the software industry whenever a software developer has market power).

183 See Klors Inc. v. Broadway-Hale Stores, 359 U.S. 207 (1959). 
from unilateral refusals to deal (which are generally legal). ${ }^{184}$ However, recent cases such as Northwest Wholesale suggest that the law of group boycotts is converging with the rule on essential facilities, and that a group boycott will not amount to a section 1 violation unless the plaintiff has been denied effective access to the market. ${ }^{185}$ Further, vigorous application of the antitrust laws to require access to standards groups may discourage group standard-setting altogether, since companies may be unwilling for a variety of reasons to discuss their product plans with certain competitors. 86

While the issue is not free from doubt, the use of antitrust doctrine to compel access to a standard-setting organization should probably be rare. ${ }^{187}$ Not every organization which attempts to set industry standards must be open to all members. ${ }^{188}$ This does not mean that standard-setting organizations should never be forced to open their doors, however. While there are good reasons to limit the use of the essential facilities doctrine, efforts to control a highly standards-driven market which appear likely to succeed may well be appropriate cases for application of the essential facilities doctrine.

184 See, e.g., Data General Corp. v. Grumman Support Servs., 36 F.3d 1147 (1st Cir. 1994). Some unilateral refusals to deal have been found to violate the antitrust laws under section 2, rather than section 1. See Aspen Skiing Co. v. Aspen Highlands Skiing Corp., 472 U.S. 585 (1985).

185 Cf. Heidt, Self-Regulation and the Useless Concept "Group Boycott, 39 Vand. L. Rev.1507 (1986).

186 See James B. Kobak Jr., Enforcers Focus on IP Issues, Nat'l L.J., May 6, 1996, at B7, B10. One way to avoid this result would be to compel competitor access only to the standard itself, and not to the group producing the standard. See generally Reidenberg, supra note _. This approach would have the advantage of requiring less government intrusion into the workings of the private group. Whether it would be effective, however, may depend on the complexity of the standards at issue and the potential for group members to obtain a lead time advantage before the standard is announced.

187 One possible approach to take in order to limit such claims is to allow government but not private suits for violations of the antitrust laws by standard-setting organizations. For a more general proposal along these lines, see Edward A. Snyder \& Thomas E. Kauper, Misuse of the Antitrust Laws: The Competitor Plaintiff, 90 Mich. L. Rev.551 (1991).

188 See National Ass'n of Review Appraisers \& Mortgage Underwriters v. Appraisal Found., 64 F.3d 1130 (8th Cir. 1995). 
A second type of anticompetitive behavior by participants in a standard-setting organization may be more amenable to antitrust treatment in certain circumstances. That behavior is the "capture" of a standard-setting group by a particular participant. In the context of Internet software markets, the most likely means of capturing a standard is by the strategic use of intellectual property rightş. 89 Two examples should suffice.

In 1992, the Video Electronics Standards Association (VESA) adopted a computer hardware standard called the VL-Bus standard, which governs the transmission of information between a computer's CPU and its peripheral devices. ${ }^{190}$ Each of the members voting to adopt the standard, including Dell Computer Corporation, was required by VESA rules to affirm that they did not own any patent rights which covered the VL-Bus standard. ${ }^{191}$ Dell's representative did in fact make such a statement. Nonetheless, Dell asserted a patent against other VESA members for using the VL-Bus standard eight months later, after the VL-Bus standard had been widely adopted. By working to adopt as a group standard a technology Dell allegedly knew was proprietary, ${ }^{192}$ Dell could obtain the help of its competitors in establishing a standard which it would ultimately be able to control. While the VL-Bus

189 In more traditional products markets, capture of standard-setting organizations sometimes takes the form of controlling the organization and using it to vote down a competitor's standard. This is what apparently happened in Allied Tube \& Conduit Corp. v. Indian Head, Inc., 486 U.S. 492 (1988), discussed supra note _. That approach will not have the same effect in industries such as the Internet software market unless the capturing party has intellectual property rights in the dominant standard. Absent such rights, competitors will alter their products to comply with the winning standard. This may require some time and expense, but the expense will be well worth it to competitors if the lock-in effects of the standard are significant.

190 See In re Dell Computer Corp., No. 931-0097 (F.T.C. 1995).

191 Id. Many standard-setting organizations, including the American National Standards Institute (ANSI) and Semiconductor Equipment and Materials International (SEMI) have similar rules. See AIPLA, Testimony Before the Federal Trade Commission on Antitrust and Intellectual Property (submitted October 1995).

192 Whether Dell in fact knew this is a matter of some dispute. In her dissent to the Commission's proposed consent decree, Commissioner Azcuenaga claimed that there was "no evidence to support such a finding of intentional conduct." Dell Computer, supra (Azcuenaga, Comm., dissenting). A Dell spokesperson indicated that after the FTC investigation, the company was "revising its procedures to ensure that its employees are 'completely up to speed on all of our patent portfolios.'" Darlene Superville, Dell to drop patent claim to PC design feature, Austin Am.-Statesman Nov. 3, 1995, at C2. 
standard has little to do with the Internet, and indeed is no longer in common use even in PC design, the problem is instructive because the IETF has historically required the same agreement by participants not to assert intellectual property ownership of Internet standards..$^{193}$

The second example involves the most common standard for file exchange of graphics over the Internet -- the "GIF" standard. ${ }^{194}$ No official group set GIF as a standard; rather, after it was released by Compuserve in 1987, GIF was apparently free for all to use and was gradually adopted by a number of Internet users (as well as developers of extension programs) during the late 1980s and early 1990s. Unisys Corporation obtained a patent in 1986 which arguably covers the compression algorithm used by the GIF standard (the LZW patent). Unisys kept largely silent about the patent while the GIF standard gained market share -whether intentionally or because they were unaware of the GIF-LZW overlap is unclear. ${ }^{195}$ In 1994, it asserted the patent against Compuserve and others who transferred graphics over the Internet using the standard. ${ }^{196}$ Unisys' actions with respect to the LZW patent were arguably intended to have an effect similar to Dell's. Though Unisys made no affirmative representation

193 Network Working Group Request for Comments No. 1602, March 1994, available at http://ds.internic.net/rfc/rfc1602.txt. To be sure, such an agreement is enforceable only against companies participating in the IETF process, or which offer their technology as a standard. It is conceivable that a patent owner not affiliated with IETF could shut down the Internet by asserting its intellectual property rights against critical Internet standards.

194 Competitors to GIF at the time included a standard called JPEG, but it suffered from certain disadvantages relative to GIF. See Michael Console Battilana, The GIF Controversy: A Software Developer's Perspective (1996) (available in electronic form from mcb@cloanto.it). More recently, a number of developers have come up with a variant of GIF called PNG which does not use the compression technology covered by the Unisys patent. $I d$.

195 Unisys spokespersons now claim that they acted against Compuserve as soon as they became aware that LZW was incorporated in GIF. See id.; Bob O'Leary, Unisys Clarifies Policy Regarding Patent Use in OnLine Service Offerings message posted to cni-copyright listserv, Jan. 10, 1995, at 10:50 am.

196 Id.; see Pat Clawson, An Open Letter to Our Colleagues in the Online Communications Community, posted on the cyberia-1 listserv, Jan. 3, 1995, at 1:00 pm. 
that the standard was not proprietary, its silence during the crucial period of standards competition allowed it to take a more mature industry by surprise.

The competitive harms of this form of capture are relatively clear. Not only does the capturing party end up with exclusive control over the market standard, converting a group standard-setting process into a de facto one, but the capturing party can use the group standard to achieve a dominant position it could not have attained in an open standards competition. Had Unisys or Dell announced up front that the standards they were backing were proprietary, it is unlikely that the affected industries would have chosen those standards. At the very least, those standards would have faced stiffer competition than they dPd.

The most likely avenue of antitrust attack against such capture does not involve section 1 at all but rather is an attempted monopolization claim under section 2.198 Attempted monopolization has three elements -- intent to monopolize, anticompetitive conduct in furtherance of that intent, and a dangerous probability of success. ${ }^{199}$ Assuming the failure to disclose relevant intellectual property rights was intentional and not an oversight, the first element should be easy to satisfy. ${ }^{200}$ Efforts to capture an industry standard in any given case would constitute anticompetitive conduct precisely in the situation where those efforts are likely to threaten monopolization -- that is, where the standard being set is one which will

197 Indeed, the future of the GIF standard is unclear. A number of software developers have stopped using the standard since Unisys' announcement. It may be that the (presumably public domain) PNG standard will replace GIF.

198 The FTC's claim against Dell was not for violation of either section of the Sherman Act, but rather was brought under section 5 of the FTC Act, which gives similar powers to the Commission. See FTC v. Sperry \& Hutchinson Co., 405 U.S. 233 (1972).

199 Spectrum Sports v. McQuillen, 113 S. Ct. 457 (1993).

200 Even where intent is in question, as it apparently was in the Dell case, an antitrust claim might be worth pursuing. An actual intent to monopolize is difficult to prove, and in some cases can be inferred from conduct. See, e.g., Handgards, Inc. v. Ethicon, Inc., 743 F.2d 1282, 1293 (9th Cir. 1984); William Inglis \& Sons Baking Co. v. ITT Continental Baking Co., 668 F.2d 1014, 1027-28 (9th Cir. 1981). See also Dratler, supra note __, at 686 ("It is therefore themeans of excluding rivals, not the underlying intent, that really matter."). 
likely dominate the industry. ${ }^{201}$ Market power may be the necessary result of patent enforcement in some cases, while in others the patent owner's control over the market stems from a failure of information in the market, a failure which the patent owner herself has induced. ${ }^{202}$ While the fact that the antitrust defendant does own intellectual property rights governing the technology suggests some caution in applying the antitrust laws, ${ }^{203}$ the mere possession of an intellectual property right will not protect its owner from a charge of dominating a market by extending the scope of that right.204 In the Dell case, the FTC

201 See James B. Kobak Jr., Enforcers Focus on IP Issues, Nat'I L.J., May 6, 1996, at B7, B9 ("a deliberate effort to sandbag competitors into adopting a standard which would then be used to exclude the same competitors from the market seems easy to condemn under monopolization and attempt-to-monopolize principles ..."). While such a determination is speculative, the same can be said of any attempted monopolization case. Factors such as the collective market share of members of the standard-setting organization or the past success of group standards may be evidence of likelihood of successful monopolization.

By contrast, Henry Perritt Jr. distinguishes the situation in which an intellectual property owner merely encourages the adoption of its standard by an independent agency, without any misrepresentations or intent to deceive. Absent such conduct, benefitting from a standard-setting body's decision does not seem to create a section 2 case. See Perritt, supra note __, at 368-70.

202 In this sense, one might think of a patent owner who fails to disclose the patent to a standard-setting group as in a position analogous to the defendant in Eastman Kodak v. Image Technical Servs., $112 \mathrm{~S}$. Ct. 2072 (1992). Where information is imperfect, markets based on that information will be imperfect also. Those in possession of the information can use their knowledge to the advantage of their competitors or consumers. See Mark R. Patterson, Product Definition, Product Information, and Market Power: Kodak in Perspective, 73 N.C.L. Rev. 185 (1994).

In the context of patents and standard-setting organizations, it is useful to distinguish two different sets of circumstances. Where the party in question possesses a patent application, it would be virtually impossible for competitors to acquire information about this potential intellectual property right, except from the patent applicant herself. Where a patent has been issued, on the other hand, it is possible for the standards group to search the patent literature themselves to ensure that no patents cover the proposed standard. However, such a search is costly and imperfect, and will therefore not necessarily prevent the patent owner from using lack of information to her advantage.

203 See, e.g., Louis Kaplow, The Patent-Antitrust Intersection: A Reappraisal, 97 Harv. L. Rev. 1813 (1984).

204 See, e.g., International Salt Co. v. United States, 332 U.S. 392 (1947). In light of this, it is somewhat surprising that the Antitrust Division has taken a position in favor of allowing intellectual property ownership of group standards by a member of the group. In a series of negotiations regarding rules promulgated by the European Telecommunications Standards Institute (ETSI), the United States put substantial pressure on ETSI 
entered into a consent decree in which Dell agreed not to assert its intellectual property rights in the VL-Bus.205 To date, the Unisys case has not been litigated.

Of course, not all patents covering standards will necessarily be anticompetitive. While one approach to standards is to require them to be intellectual property-free (IETF's approach, at least until recently), intellectual property can coexist with procompetitive standard-setting. For example, ANSI and other groups do not require that an intellectual property owner give up any claim to a standard, but merely that they license their intellectual property rights on a reasonable basis. Other examples of reasonable and even procompetitive uses of intellectual property in the standard-setting context are possible. ${ }^{206}$ It is only in that subset of cases where the patent is used as a competitive weapon that concerns about market control are implicated? 07

to back down from its original rule requiring disclosure and nondiscriminatory licensing of member intellectual property rights embodied in ETSI standards.

To be sure, this approach has precedent in some earlier U.S. cases condemning patent pools and cross licenses. See United States v. New Wrinkle, 342 U.S. 371 (1951). Further, there were apparently some legitimate complaints about the reciprocity of the ETSI licensing provisions. See Allen N. Dixon, The ETSI Complaint and the European Commission's Communication on Standardization (working paper 1995); Prins \& Schiessl, The New Telecommunications Standards Institute Policy: Conflicts Between Standardisation and Intellectual Property Rights, 8 Eur. Intell. Prop. Rev. 263 (1993). Nonetheless, the Division's approach seems at least to be in some tension with the FTC's arguments in the Dell case, in which the government opposed efforts by one party to use intellectual property rights to capture group standards with market power. For discussions of the evolving ETSI rule on intellectual property rights, see Raymond T. Nimmer, Standards, Antitrust and Intellectual Property, in Intellectual Property Antitrust (P.L.I. 1995); Shurmer \& Lea, supra note __, at 391-96; Epstein,supra note , at 873-76.

205 See Dell Computer, supra note _._.

206 For example, Eolas Technologies owns a patent which allegedly covers the technology of embedding executable content in the World Wide Web, and which (if valid) would allow it to control the production of "applets" by Sun and others. Eolas has agreed to license the patent royalty-free to any company which will adopt a particular open applications program interface (API). In effect, Eolas is using its potential control over the applet market to force the industry to an open rather than a closed set of standards. See Michael Doyle, Proposing a Standard Web APIDr. Dobb's J, Feb. 1996, at __.

207 In rare cases, a rule precluding patents on standards might be found to be anticompetitive. In In re Am. Soc'y of Sanitary Eng., 106 FTC 324, 328-29 (1985), the FTC alleged that a standard-setting organization could not refuse to consider revising its standards to include a new product solely on the grounds that that product was patented. The case was settled by consent decree. It is significant that the standard in question 
Even where an act is anticompetitive, it is possible to argue that application of the antitrust laws is not warranted to the extent that non-antitrust legal principles cannot more effectively be brought to bear on the same conduct. ${ }^{208}$ In the particular context of the Dell case, there are several possible alternatives to antitrust analysis. First, Dell's nondisclosure of its patent violated a rule of the standard-setting organization requiring disclosure of intellectual property rights. As a result, some commentators have argued that a breach of contract claim is the appropriate response to Dell's actions and that invoking antitrust is unwarranted. ${ }^{209}$ It is not clear that this argument has much force in the Dell case. First, not all of the parties injured by Dell's action were members of VESA, and non-members presumably lack standing to sue for breach of contract. ${ }^{210}$ Second, the damages for breach of such a contract may be limited in ways that mean Dell would not have to compensate even VESA members for the full value of the competitive harm they have incurred.211 Finally, not

was inclusive rather than exclusive, and so allowing the complainant's product to be included would not have restricted the rights of other members to make use of other technology covered by the standard. Nonetheless, the case should serve as a caution for rules such as IETF's requiring participants to relinquish their intellectual property rights.

208 On this point, see McGowan, supra note __, at __; see also Penelope Preovolos, Litigation in the Interface: Connecting to Essential Facilities, http://www.portal.com/ recorder/preovolos.html (antitrust is a "blunt instrument" to be used only when other alternatives are insufficient). The doctrinal value of this argument is not clear. Federal law does not ordinarily defer to state law remedies, except in certain highly specialized constitutional circumstances not relevant here. On the other hand, to the extent that the argument is over the desirability of extending antitrust to a particular type of cases, the fact that there are non-antitrust ways of dealing with those cases is certainly relevant.

209 See AIPLA Comments,supra note _._.

210 Restatement (Second) Contracts $\S 302$ distinguishes between intended beneficiaries, who may enforce contracts, and incidential beneficiaries, who generally may not. Non-members of VESA presumably fall within the latter category.

211 Contract damages are ordinarily conceived as "expectation damages." In this case, the expectancy is somewhat speculative, since it is difficult or impossible to predict what would have happened if the patent had been disclosed. In such a circumstance, one might envision a remedy of restitution, under which the defendant disgorges its profits to the group. Restitution is a remedy that is doctrinally available in contract law, despite its tension with contract theory. See Doug Laycock, Modern American Remedies 553-57 (1994). However, even a restitutionary remedy is in theory insufficient to compensate society for the loss it suffers from 
all organizations have such a rule, and in some cases (such as the Unisys GIF standard) there is no contract at all.

Alternatively, it is possible that Dell could be liable to VESA or its members on some sort of fraud or misrepresentation theory. This is perhaps more promising than contract, in that if offers plaintiffs the possibility of recovering their actual damages. But a fraud theory must of necessity be based on some duty to the plaintiff, which would seem to preclude suits by consumers or by non-members of the group.

Perhaps a more likely approach is to try to solve the problem within the confines of intellectual property law. A rule requiring compulsory licensing in such cases would solve the problem, but intellectual property law has historically rejected compulsory licensing in most circumstances. $^{212}$ A final non-antitrust approach to the Dell problem is to apply the doctrine of equitable estoppel. There are a number of precedents suggesting that companies who fail to disclose a known patent to a standard-setting group may be estopped from later asserting that patent against members of the group once they have adopted the patented technology as a standard. ${ }^{213}$ One such case even involves failure to assert a patent during a de facto standards competition, and is therefore potentially applicable to the Unisys GIF problem. ${ }^{214}$ To the

anticompetitive pricing, since the cost to society from such pricing exceeds the benefit obtained by the defendant. This excess loss is referred to as the "deadweight loss" from monopoly.

212 See Robert P. Merges, Contracting Into Liability Rules: Institutions Supporting Transactions in Intellectual Property Rights 84 Cal. L. Rev.__ (forthcoming 1996).

213 See Stambler v. Diebold, Inc., 11 U.S.P.Q.2d 1709, 1714-15 (E.D.N.Y. 1988), aff'd 878 F.2d 1445 (Fed. Cir. 1989) (unpublished); Potter Instrument Co. v. Storage Technology Corp., 207 U.S.P.Q. 763, 766 (E.D. Va. 1980), aff'd 641 F.2d 190 (4th Cir. 1981); see also Wang Lab, Inc. v. Mitsubishi Elec. Am. Inc., 29 U.S.P.Q.2d 1481, 1495-96 (C.D. Cal. 1993) (equitable estoppel claim raised triable issue of fact). The Fourth Circuit did not reach the equitable estoppel issue in Potter, but indicated in dictum that it would be inclined to find such an estoppel. 641 F.2d at 192. Estoppel from misleading silence is possible, but rare, under Federal Circuit precedent. See Jamesbury Corp. v. Litton Indus. Prods., 839 F.2d 1544, 1553 (Fed. Cir. 1988) (minority opinion).

214 See Stryker Corp. v. Zimmer, Inc., 741 F. Supp. 509 (D.N.J. 1990). 
extent that equitable estoppel will prevent enforcement of intellectual property rights in such a situation, it would appear to obviate the need for antitrust action. However, the uncertainty associated with this rule ${ }^{215}$ suggests continued antitrust vigilance in this area, at least as a backstop.

\section{Conclusion}

Market forces operate differently on the Internet than they do in most other industries. A number of different effects combine to produce a powerful incentive for standardization of products and interoperability elements. These standardization effects drive the market towards a single leader (the de facto standard-setter) or, in certain cases, towards a standard set collectively by competitors.

Antitrust has an important role to play in maximizing competition in this context. Unfortunately, traditional antitrust analysis may lead courts and regulators to act inappropriately in their efforts to preserve competition. In particular, section 2 monopolization claims may prove ineffective in controlling dominant firms whose product has become the de facto standard, while section 1 may prove too effective in restraining private standard setting organizations from offering a viable alternative. In my view, antitrust cannot and should not attempt to interfere with the broad workings of standardized markets, but it can maximize competition in the context of those markets by ensuring that no party can capture the power of a standard through anticompetitive conduct. Antitrust may need to take account of the peculiar economics of the Internet, but it does not need to be discarded entirely.

\footnotetext{
215 For example, the Federal Circuit has never adopted it in the context of standard-setting, and it is not clear that it would apply to copyright as well as patent cases.
} 


\section{Figure 1}

$\mathrm{D}$ reflects market demand, $\mathrm{MC}_{\mathrm{i}}$ is the marginal cost of a single firm in the industry, and $\mathrm{AC}_{\mathrm{i}}$ is the average cost of the firm. 
Figure 2

$\mathrm{D}$ reflects market demand, MR reflects marginal revenue for a monopolist (derived from the demand curve), $\mathrm{MC}_{1}$ is the marginal cost of firm 1 , and $\mathrm{MC}_{2}$ is the marginal cost of firm 2 . Each firm will set production where its marginal cost equals marginal revenue. That will result in greater output and a lower price in the case of firm 1, which has a lower cost structure. 